\title{
LA PRUEBA EN VIOLENCIA SEXUAL Y EN VIOLENGIA DE GÉNERO: ESPECIAL REFERENCIA A LA PRUEBA DE ADN
}

\author{
A PROVA EM VIOLÊNCIA SEXUAL E A VIOLENCIA CONTRA A MULHER: \\ REFERÊNCIA ESPECIAL A PROVA DE DNA
}

\author{
THE EVIDENCE IN SEXUAL VIOLENCE AND VIOLENCE AGAINST \\ WOMEN: SPECIAL REFERENCE TO DNA TESTING
}

Inés C. Iglesias Canle*

\begin{abstract}
RESUMEN: Los agresores se procuran, y más aún en este ámbito de delitos contra la vida y la libertad sexual en las relaciones de pareja, de unos hechos en lo que respecta al lugar de comisión del delito, en las que resulta muy difícil disponer de pruebas más allá de la declaración de la víctima. La prueba de ADN puede tener una gran virtualidad a la hora de acreditar determinadas circunstancias que tengan relación con la comisión del hecho punible. De ello se ocupa este estudio, incidiendo en la regulación existente en el ordenamiento jurídico español en materia de obtención de prueba biológica y valoración de la prueba genética, que considera los distintos pasos desde la recogida de las fuentes de prueba hasta su apreciación judicial.
\end{abstract}

PALABRAS-CLAVES: Prueba de ADN. Violencia sexual. Mujer.

RESUMO: Os agressores são procurados, principalmente neste âmbito dos delitos contra a vida e a liberdade sexual nos relacionamentos, por fatos relativos ao lugar de cometimento dos delitos, o que torna muito difícil dispor de provas além da declaração das vítimas. A prova de DNA pode ter uma grande virtude no momento de atribuir determinadas circunstâncias que tenham relação com o cometimento do fato punível. Disso se ocupa este trabalho, incidindo na regulação existente no ordenamento jurídico espanhol em matéria de obtenção de prova biológica e valoração da prova genética que considera os distintos passos desde a recolhimento das fontes de prova até a sua apreciação judicial.

PALAVRAS-CHAVE: Prova de DNA. Violência sexual. Mulher.

ABSTRACT: The attackers were seeking, and even more in this area of crimes against life and sexual freedom in relationships, in facts as regards the place of commission of the crime, which very difficult to have evidence beyond the testimony of the victim. DNA testing can have great potentiality when demonstrating certain circumstances that pertain to the commission of the crime. It occupies this study, focusing on the existing regulation in the Spanish legal system to obtain evidence of biological and genetic evaluation of evidence, that consider the various steps from the collection of the sources of evidence to its judicial appreciation.

KEYWORDS: DNA evidence. Sexual violence. Woman.

* Universidad de Vigo. Profesora Titular de Derecho Procesal. 


\section{INTRODUCCIÓN}

Cuando nos referimos a la prueba en violencia sexual estamos pensando en cómo se pueden acreditar en el acto del juicio, a través de los medios de prueba previstos legalmente, determinadas circunstancias y elementos que forman parte del supuesto de hecho del tipo penal, que contempla la supuesta actuación delictiva. Los agresores se procuran, con carácter general, y más aún en este ámbito de delitos contra la vida y la libertad sexual en las relaciones de pareja, de unas circunstancias en lo que respecta al lugar de comisión del hecho punible, en las que resulta muy difícil encontrarnos con pruebas más allá de la declaración de la víctima, de los parientes más cercanos o de la prueba pericial practicada con el consentimiento de la víctima.

En este contexto, es fácil entender que las pruebas en violencia sexual, particularmente en el ámbito de la violencia intrafamiliar y de género, se circunscriben normalmente a la declaración de la víctima y de los parientes que convivan con ella y, finalmente, aunque no por ello en último lugar, la prueba de ADN.

En relación a la declaración de la víctima o de parientes del procesado en línea directa ascendente y descendente, sus hermanos consanguíneos o uterinos y los colaterales consanguíneos hasta el segundo grado civil, así como los parientes naturales a que se refiere el art. 261.3 ${ }^{\circ}$ LECrim. (hijos naturales respecto de la madre en todo caso, y respecto del padre cuando estuvieren reconocidos, así como la madre y el padre en iguales casos) debemos recordar la dicción literal del art. 416 LECrim. que dispensa a estas personas de la obligación de declarar. El juez instructor advertirá al testigo que se halle comprendido en el párrafo anterior, que no tiene obligación de declarar en contra del procesado; pero que puede hacer las manifestaciones que considere oportunas, consignándose la contestación que diere a esta advertencia. ${ }^{1}$

Por tanto, en nuestra opinión, la prueba de ADN puede tener una gran virtualidad a la hora de acreditar determinadas circunstancias que tengan relación con

1 Para un estudio de la problemática suscitada por el art. 416 LECrim. v. ALAÑÓN OLMEDO F. (Algunos apuntes sobre el contenido del artículo 416 de la Ley de Enjuiciamiento Criminal), "Violencia de género: perspectiva jurídica y psicosocial”, Tirant lo Blanch, Valencia, 2009, págs. 63 y ss.).

Entendemos con este autor que "la persecución de los delitos englobados dentro de la categoría "violencia de género" está mediatizada por el ámbito en el que se producen. Relaciones que fueron de afecto, íntimas, aparecen en la génesis de estos tipos y justifican su propia existencia, tal y como nos enseña la exposición de motivos de la Ley de medidas de protección integral contra la violencia de género 1/2004 de 28 de diciembre. Esta situación provoca la colisión de intereses, los del Estado en la persecución de los delitos y los de la propia víctima para quien su derecho a la intimidad personal y familiar se encuentra en juego.

Este contexto justifica el contenido del art. 416 LECRim., precepto cuya aplicación puede dificultar la posibilidad de plasmar en los hechos probados de una sentencia la realidad acaecida. El análisis del precepto ofrece una rica problemática y es dentro de la misma donde se debe concluir en la dificultad que presenta su elusión desde la opción efectuada por la víctima, lo que a la postre deriva en situaciones nada deseables de impunidad. Habrá de ser el legislador el que acometa una reforma del texto que acomode los intereses en conflicto y, desde luego, permita una persecución del delito acorde con la lacra que representa la violencia de género en nuestra sociedad". 
la comisión del hecho punible, más allá de la declaración de la víctima y del testimonio de terceras personas.

Además, este medio de prueba goza de reconocimiento y aceptación internacional, sin que su admisión en un proceso afecte al derecho de defensa y a la presunción de inocencia del imputado, ya que se trata de que se someta a una mínima intervención corporal previa (extracción de una mínima muestra de cabellos, sangre o saliva), de resultado incierto y que tanto puede resultar favorable tanto a la defensa como a la acusación. Este difícil equilibrio, entre los derechos del imputado, de un lado, y el derecho de reparación de la víctima y al ejercicio del ius puniendi del Estado de otro, ha sido objeto de estudio por parte de la doctrina de nuestro Tribunal Constitucional y, hoy día, no presenta dudas su posible adopción en el marco de una investigación criminal en curso, siempre que se cumplan los presupuestos para su válida adopción, como veremos, básicamente, proporcionalidad y legalidad de la medida de intervención corporal que debe adoptarse previamente, acordada en el curso de un proceso penal mediante resolución judicial motivada, en la que se plasme el juicio de proporcionalidad en relación a los derechos fundamentales en conflicto, y con respeto absoluto a la legalidad vigente, que debe prever con carácter previo la medida de intervención corporal de que se trate ${ }^{2}$.

La prueba de ADN en nuestros tribunales es una realidad, que debe valorarse positivamente, siempre que se interpreten adecuadamente los análisis genéticos introducidos como elemento de prueba en el proceso penal, particularmente, a través de la prueba pericial, con el debido respeto a los derechos fundamentales en conflicto, tanto de la víctima, como del supuesto agresor.

De todo ello daremos debida cuenta, concentrando nuestro esfuerzo en ofrecer claridad en un terreno no siempre debidamente tratado por el legislador y que está necesitado de una reflexión más detenida.

Es necesario que la nueva Ley de Enjuiciamiento Criminal realice una regulación acabada de las denominadas intervenciones corporales, diligencias que hay que practicar, tanto sobre la víctima, con su consentimiento, como sobre el agresor, con su consentimiento o previa la correspondiente autorización judicial de la medida, para obtener las muestras dubitadas de material biológico hallado tras la agresión sexual, en el primer caso, e indubitadas en cuanto se practiquen sobre el supuesto agresor, a efectos de su posterior análisis genético. Asimismo, la introducción de los resultados obtenidos y su valoración por el órgano jurisdiccional a partir de la definición y configuración que se haga de la prueba pericial en la futura Ley de Enjuiciamiento Criminal, son temas urgentes que también debiera abordar el legislador.

2 V. en cuanto al concepto, naturaleza jurídica, constitucionalidad y presupuestos para la adopción de las medidas de intervención corporal mi trabajo sobre "Investigación penal sobre el cuerpo humano y prueba científica", Madrid, 2004, págs. 14 y ss. 
No obstante, a todas estas cuestiones concernidas en el tema que nos ocupa, trataremos de darle respuesta con la regulación vigente, sin renunciar a realizar esta llamada al legislador, que consideramos urgente dada la importancia y trascendencia de estas nuevas técnicas de investigación criminal, que tienen difícil encaje, como veremos, en el actual marco legal procurado por la vigente Ley de Enjuiciamiento Criminal, la cual no pudo en su día prever estos avances en materia de investigación criminal.

\section{LAS INTERVENCIONES CORPORALES Y SU REGULACIÓN LEGAL EN EL ORDENAMIENTO JURÍDICO ESPAÑOL}

Por intervenciones corporales entendemos las medidas de investigación que se realizan sobre el cuerpo de las personas vivas con el fin de descubrir circunstancias fácticas que sean de interés para el proceso, en relación con las condiciones o el estado físico o psíquico del sujeto, o con el fin de descubrir objetos escondidos en él ${ }^{3}$.

Dentro de las diligencias practicables en el curso del proceso penal, como actos de investigación o de prueba recayentes sobre el cuerpo del imputado o de terceros, cabe distinguir entre inspecciones y registros corporales, de un lado, e intervenciones corporales, de otro, en los términos que propugna nuestro Tribunal Constitucional en su STC 207/1996. Por tanto, una de las notas más características de estas diligencias es su heterogeneidad y, en segundo lugar, su naturaleza pericial, dado que tanto para su obtención como para su posterior análisis se requieren conocimientos especializados provenientes fundamentalmente del ámbito de la Medicina Forense.

La introducción de estas diligencias en el ordenamiento jurídico español viene de la mano de la doctrina científica y de la jurisprudencia constitucional, particularmente, de la ya mencionada STC 207/1996, de 16 de diciembre. Más tarde, en respuesta a tal doctrina constitucional, la disposición final primera en su apartado 1 c) de la Ley Orgánica 15/2003, de 25 de diciembre, de modificación del Código Penal, dotó en su día de nueva redacción al art. 363 LECrim. Concretamente, introdujo un nuevo apartado del siguiente tenor: «Siempre que concurran acreditadas razones que lo justifiquen, el Juez de Instrucción podrá acordar, en resolución motivada, la obtención de muestras biológicas del sospechoso que resulten imprescindibles para la determinación de su perfil de ADN. A tal fin, podrá decidir la práctica de aquellos actos de inspección, reconocimiento o intervención corporal que resulten adecuados a los principios de proporcionalidad y razonabilidad».

Con ello, el legislador pretendía dotar de cobertura legal a la práctica de las diligencias de intervención corporal consistentes en la extracción de muestras biológicas

3 Partimos a estos efectos de la definición que proporciona GONZÁLEZ-CUÉLLAR SERRANO (Proporcionalidad y derechos fundamentales en el proceso penal, Madrid, 1990, pág. 290), pero sin entender la coerción física como un rasgo definidor, dada la actual regulación del ordenamiento jurídico, español en los términos que precisamos a continuación. 
del sospechoso con la finalidad de practicar sobre ellas las pruebas genéticas que resulten necesarias con fines de investigación criminal. La situación legal previa justificaba esta norma, al tiempo que permitió declararla insuficiente y cuasi inconstitucional.

En efecto, antes de que el legislador emprendiera la reforma legal tendente a procurar la regulación legal de la denominada prueba genética, reinaba una absoluta anomia en el ámbito de las intervenciones corporales. Tanto es así que el Tribunal Constitucional, tras un primer pronunciamiento (STC 37/1989, de 15 de febrero) en el que con un muy discutible criterio convalidaba la práctica de intervenciones corporales leves que no afectasen al «derecho al pudor o recato corporal», optaba por entender que, en tanto no se regulasen expresamente, en la medida en que afectan a una pluralidad de derechos fundamentales, básicamente, el derecho a la integridad física, las diligencias de intervención corporal debían considerarse diligencias prohibidas porque su práctica resultaría contraria a los principios y postulados constitucionales.

Se trataba simplemente de asegurar el marco constitucional que procura una convivencia pacífica y garantiza el orden público tutelado por la ley, y por ello resultaban prohibidas injerencias en los derechos fundamentales, realizadas con fines de investigación criminal, que no estuviesen amparadas en una ley procesal previa. El Tribunal Constitucional en su sentencia 207/1996, de 16 de diciembre, resultaba tajante al respecto al afirmar que «mediante el reconocimiento del derecho fundamental a la integridad física y moral (art. 15 CE) se protege la inviolabilidad de la persona, no sólo contra ataques dirigidos a lesionar su cuerpo o espíritu, sino también contra toda clase de intervención en esos bienes que carezca de consentimiento de su titular».

Consiguientemente, la limitación del derecho fundamental a la integridad física debía realizarse mediante una ley orgánica y con observancia de los requisitos de razonabilidad y proporcionalidad, a que, por otra parte, debe sujetarse toda medida restrictiva de derechos fundamentales de la persona.

Posteriormente, el legislador español en la Ley Orgánica 10/2007, de 8 de octubre, lleva a cabo una reforma en la que trata de adecuar el marco del actual proceso penal a las exigencias derivadas de la introducción en el mismo de modernas técnicas de investigación criminal.

En efecto, en la investigación de los delitos se ha permitido la introducción de la información obtenida a partir del ADN para identificar al culpable de un delito, tanto en España como en otros países de nuestro entorno jurídico, si bien, como reconoce el legislador en la exposición de motivos de esta norma, no con pocos problemas en lo que se refiere a la obtención y registro de los datos genéticos de cara a su ulterior utilización en el curso de investigaciones criminales surgidas con posterioridad.

La posible introducción del ADN como técnica de investigación criminal surge en el contexto de la Unión Europea a partir de la Recomendación (92) 1, de 10 de febrero de 1992, de su Comité de Ministros, y se sigue insistiendo en su virtualidad y 
eficacia práctica en las Resoluciones del Consejo de Europa relativas al intercambio de resultados de análisis de ADN, de 9 de junio de 1997 y de 25 de julio de 2001 y, últimamente, en las normas recogidas en el Reglamento de Eurojust relativas al tratamiento y a la protección de datos personales, aprobado por el Consejo de Europa el 24 de febrero de 2005 y, más recientemente, en el Convenio de Prüm ${ }^{4}$, que ha influido directamente, como veremos, en la elaboración y aprobación de la Ley española objeto de análisis ${ }^{5}$, y en la Decisión-Marco 2008/615/JAI del Consejo, de 23 de junio de 2008, sobre la profundización de la cooperación transfronteriza, en particular en materia de lucha contra el terrorismo y la delincuencia transfronteriza ${ }^{6}$.

Los problemas de inserción en el actual marco constitucional han sido objeto de estudio y resolución adecuada en la jurisprudencia constitucional, sobre todo, a partir del pronunciamiento de la STC 207/1996, de 16 de diciembre, al que ya hemos hecho referencia anteriormente ${ }^{7}$. Posteriormente, se ha llevado a cabo el cumplimiento de la exigencia constitucional sobre la legalidad y proporcionalidad de las medidas de intervención corporal, como paso previo a la obtención de la muestra indubitada para su posterior análisis de ADN, tal y como se deriva de la doctrina constitucional antes referida, en la disposición final primera de la Ley Orgánica 15/2003, de 25 de noviembre, de modificación del Código Penal, en los términos antes referidos.

Así, como hemos adelantado, la modificación consistió fundamentalmente, a los efectos que ahora nos interesan, en la nueva redacción del art. 363 LECrim., de manera que se pueda obtener ADN a partir de muestras biológicas del sospechoso para su posterior contraste con perfiles genéticos provenientes de pruebas halladas en el lugar del delito, lo que evidencia, a nuestro juicio, la falta de cobertura constitucional para la práctica de otras diligencias de investigación corporal no contempladas por esta norma².

4 Ratificado por nuestro país por INSTRUMENTO de ratificación de España del Convenio relativo a la profundización de la cooperación transfronteriza, en particular en materia de lucha contra el terrorismo, la delincuencia transfronteriza y la migración ilegal, hecho en Prüm el 27 de mayo de 2005.

5 Sobre estos aspectos, cfr. SANZ HERMIDA, A.M., "La protección de datos personales en la transferencia automatizada de perfiles de ADN entre Estados miembros de la UE», en este mismo número de Iustel.

6 Esta Decisión establece las disposiciones de protección de datos que rigen la transferencia automatizada de perfiles de ADN, datos dactiloscópicos y datos de registros nacionales de matriculación de vehículos. La Decisión marco 2008/977/JAI, de 27 de noviembre de 2008, relativa a la protección de datos personales tratados en el marco de la cooperación policial y judicial no se aplica en este ámbito, como se señala en el párrafo preliminar (39).

7 V. en este sentido el estudio llevado a cabo en mi obra Investigación penal sobre el cuerpo humano..., op. cit., págs. 15 y ss.

8 De las consecuencias derivadas de esta reforma legal nos ocupamos en la obra colectiva " Investigación y prueba y proceso penal", v. IGLESIAS CANLE, I. C, La nueva regulación de las medidas de intervención corporal en el art. 363.2 LECrim.: la quiebra del principio de legalidad, págs. 175 y ss.

V. también PÉREZ MARÍN, M. A., Inspecciones, registros e intervenciones corporales. Las pruebas de ADN y otros métodos de investigación en el proceso penal, Valencia, 2.008. 
Pero la reforma no contempló la posibilidad de crear una base de datos en la que, de manera centralizada, se almacenase el conjunto de los perfiles genéticos, a fin de que pudiesen ser utilizadas, posteriormente, en investigaciones distintas futuras, incluso sin el consentimiento expreso del titular de los datos.

Este es el objetivo fundamental de la norma que analizamos, la Ley Orgánica 10/2007, de 8 de octubre, reguladora de la base de datos policial sobre identificadores obtenidos a partir del ADN, si bien, como veremos, la coerción jurídica por la que apuesta, está supeditada a la existencia de un perfil genético indubitado que, a su vez, requiere una previa intervención corporal voluntaria, lo que, a todas luces, resulta un obstáculo de difícil justificación en el contexto de una investigación criminal por delitos graves.

No olvidemos, que el ámbito de actuación de estas técnicas de investigación criminal se refiere fundamentalmente a los delitos violentos contra la vida y la libertad sexual de las personas, en los que la proporcionalidad de la injerencia en los derechos fundamentales a la integridad física y a la intimidad se cumple escrupulosamente, razón por la cual no entendemos la redacción dada a la disposición adicional tercera de esta norma.

El legislador en la Ley Orgánica 10/2007 establece que "para la investigación de los delitos enumerados en la letra a) del apartado 1 del artículo 3, la policía judicial procederá a la toma de muestras y fluidos del sospechoso, detenido o imputado, así como del lugar del delito. La toma de muestras que requieran inspecciones, reconocimiento o intervenciones corporales, sin consentimiento del afectado, requerirá en todo caso, autorización judicial mediante auto motivado, de acuerdo con lo establecido en la Ley de Enjuiciamiento Criminal".

Los delitos a que se refiere el artículo 3.1 a) son "delitos graves y, en todo caso, los que afecten a la vida, la libertad, la indemnidad o la libertad sexual, la integridad de las personas, el patrimonio siempre que fuesen realizados con fuerza en las cosas, o violencia o intimidación en las personas, así como en los casos de la delincuencia organizada, debiendo entenderse incluida, en todo caso, en el término delincuencia organizada la recogida en el art. 282 bis, apartado 4, de la Ley de Enjuiciamiento Criminal en relación con los delitos enumerados".

Es evidente que el legislador se está refiriendo a un ámbito muy determinado en el que estaría plenamente justificada la vis o coerción física para la obtención del perfil genético del sospechoso, tal y como sucede en el Derecho Comparado ${ }^{9}$, atendiendo fundamentalmente al dato de la gravedad delictiva y a la idoneidad y necesidad de la medida, así como a la proporcionalidad en sentido estricto, que debe argumentarse suficientemente en el auto judicial que, a falta de consentimiento del sujeto pasivo, debe dictar el órgano judicial competente.

9 Un estudio pormenorizado de la regulación de las medidas de intervención corporal en el Derecho Comparado se recoge en mi obra ya citada IGLESIAS CANLE, I. C., Investigación penal..., op. cit. 
Pero el no haber abordado tal posibilidad en forma explícita lleva a considerar la negativa como un indicio en contra del sospechoso o incluso, en algunos casos, como un delito de desobediencia grave a la autoridad judicial, sin que tal consecuencia jurídica sea útil al efecto de perseguir adecuadamente determinadas conductas delictivas graves como las que estamos analizando.

Es evidente que se ha perdido una nueva oportunidad de solucionar las muchas incógnitas que la parca regulación de las medidas de intervención corporal planteaban, incluso, en lo que se refiere a las que permiten la introducción de la prueba genética en nuestro proceso penal. La apuesta por la coerción jurídica, que analizamos seguidamente, parte pues de un punto de origen viciado por la defectuosa e insuficiente previsión legal, al requerir para la obtención de la muestra objeto de análisis genético, consentimiento o autorización judicial no coactiva, tal y como están entendiendo nuestros tribunales ${ }^{10}$.

El artículo 1 de esta ley crea la base de datos policial de identificadores obtenidos a partir del $\mathrm{ADN}$, que integrará los ficheros de esta naturaleza de titularidad de las Fuerzas y Cuerpos de Seguridad del Estado tanto para la investigación y averiguación de los delitos, como para los procedimientos de identificación de restos cadavéricos o de averiguación de personas desaparecidas.

Se inscribirán en esa base de datos policial los identificadores obtenidos a partir del ADN que se refieran a los siguientes datos:

a) Los datos identificativos extraídos a partir del $\mathrm{ADN}$ de muestras o fluidos que, en el marco de una investigación criminal, hubieran sido hallados u obtenidos a partir del análisis de las muestras biológicas del sospechoso, detenido o imputado cuando se trate de delitos graves y, en todo caso, los que afecten a la vida, la libertad, la indemnidad o la libertad sexual, la integridad de las personas, el patrimonio siempre que fuesen realizados con fuerza en las cosas, o violencia o intimidación en las personas, así como en los casos de la delincuencia organizada, debiendo entenderse incluida, en todo caso, en el término delincuencia organizada la recogida en el art. 282 bis del apartado 4 de la Ley de Enjuiciamiento Criminal en relación con los delitos enumerados.

b) Los patrones identificativos obtenidos en los procedimientos de identificación de restos cadavéricos o de averiguación de personas desaparecidas.

${ }^{10}$ V. en este sentido resoluciones, como la del Juzgado número 2 de 0 Carballiño de 16 de marzo de 2.006, en la que en el auto que acuerda la medida, se le advierte al destinatario de la misma de que se le notifique para que acceda voluntariamente a someterse a la realización de lo acordado (extracción de saliva recogida en hisopos o extracción de sangre a los efectos de obtener muestras para la determinación de su ADN), con apercibimiento expreso de posible delito de desobediencia a la autoridad judicial en caso contrario, con advertencia de la valoración que de su negativa quepa hacerse en relación con los indicios ya existentes. 
La inscripción en la base de datos policial de los identificadores obtenidos a partir del ADN a que se refiere este apartado, no precisará el consentimiento del afectado, el cual será informado por escrito de todos los derechos que le asisten respecto a la inclusión en dicha base, quedando constancia de ello en el procedimiento.

A continuación el mismo art. 3 de esta ley precisa que "igualmente, podrán inscribirse los datos identificativos obtenidos a partir del ADN cuando el afectado hubiere prestado expresamente su consentimiento", por lo que en estos casos no será posible imponer la inscripción del perfil genético coactivamente, esto es, sin su consentimiento, con lo que tampoco surtirá efectos la coerción jurídica a la que nos estamos refiriendo, salvo que se obtenga tal información de la transferencia proveniente de un tercer Estado Miembro, en los términos que contempla la Decisión Marco 2008/615 JAI, a la que acto seguido haremos referencia.

De la lectura del art. 7.3 de esta norma se deriva la coerción jurídica, a partir de la previa inscripción del perfil genético, y la circunscribe a determinados supuestos cuando dispone que "podrán cederse los datos contenidos en la base de datos:

a) A las autoridades Judiciales, Fiscales o Policiales de terceros países de acuerdo con lo previsto en los Convenios Internacionales ratificados por España y que estén vigentes.

b) A las Policías Autonómicas con competencia estatutaria para la protección de las personas y bienes para el mantenimiento de la seguridad pública, que únicamente podrá utilizar los datos para la investigación de los delitos enumerados en la letra a) del apartado 1 del artículo 3 de esta ley o, en su caso, para la identificación de cadáveres o averiguación de personas desaparecidas.

c) Al Centro Nacional de Inteligencia, que podrá utilizar los datos para el cumplimiento de sus funciones relativas a la prevención de tales delitos, en la forma prevista en la Ley 11/2002, de 6 de mayo, reguladora del Centro Nacional de Inteligencia”.

Tal previsión debe completarse con lo dispuesto en el art. 9 de la misma norma que establece el tiempo para la cancelación, rectificación y acceso a los datos en los términos siguientes:

1. La conservación de los identificadores obtenidos a partir del ADN en la base de datos objeto de esta ley no superará:

El tiempo señalado en esta ley para la cancelación de los antecedentes penales cuando se hubiese dictado sentencia condenatoria firme o absolutoria por la concurrencia de causas eximentes por falta de imputabilidad o culpabilidad, salvo resolución judicial en contrario.

En todo caso se procederá a su cancelación cuando se hubiese dictado auto de sobreseimiento libre o sentencia absolutoria por causas distintas de las mencionadas en el epígrafe anterior, una vez que sean firmes dichas resoluciones. En el caso de sospechosos no imputados, la cancelación de los identificadores inscritos se producirá transcurrido el tiempo señalado en la ley para la prescripción del delito.

En los supuestos en que la base de datos existiesen diversas inscripciones de una misma persona, correspondientes a distintos delitos, los datos y patrones identificativos inscritos se mantendrán hasta que finalice el plazo de cancelación más amplio. 
1. Los datos pertenecientes a personas fallecidas se cancelarán una vez el encargado de la base de datos tenga conocimiento del fallecimiento. En los supuestos contemplados en el art. 3.1 b)11, los datos inscritos no se cancelarán mientras sean necesarios para la finalización de los correspondientes procedimientos.

2. EL ejercicio de los derechos de acceso, rectificación y cancelación en relación con la base de datos policial de identificadores obtenidos a partir del ADN se podrá efectuar en los términos establecidos en la Ley Orgánica 15/1999, de 13 de diciembre, y en su normativa de desarrollo.

3. Los identificadores obtenidos a partir del ADN respecto de los que se desconozca la identidad de la persona a la que corresponden, permanecerán inscritos en tanto se mantenga dicho anonimato. Una vez identificados, se aplicará lo dispuesto en este artículo a efectos de su cancelación. ${ }^{12}$

Este régimen jurídico debe completarse con lo dispuesto por la Decisión-Marco 2008/615/JAI del Consejo, de 23 de junio de 2008, sobre la profundización de la cooperación transfronteriza, en particular en materia de lucha contra el terrorismo y la delincuencia transfronteriza, aplicable a la transmisión transfronteriza de datos en este ámbito.

La Decisión-Marco 2008/615 JAI tiene por objeto intensificar la cooperación transfronteriza, en particular, la que se refiere al intercambio de información entre las autoridades responsables de la prevención y persecución de delitos. Para ello, tiene normas que se refieren, en relación al tema que nos ocupa, a disposiciones sobre las condiciones y procedimientos de transferencia automatizada de perfiles de ADN.

En efecto, en el art. 2 se contempla expresamente la creación de ficheros nacionales de análisis de ADN y dice expresamente que "Los Estados miembros crearán y mantendrán ficheros nacionales de análisis de ADN para los fines de la persecución de delitos. El tratamiento de los datos almacenados en esos ficheros en virtud de la presente Decisión se llevará a cabo de conformidad con la presente Decisión y con arreglo al Derecho interno aplicable al tratamiento". A continuación, se hace expresa mención a la exigencia de que el perfil genético que conste en la base de datos nacional debe estar referenciado. Los índices de referencia contendrán exclusivamente perfiles de ADN obtenidos a partir

${ }^{11}$ Art. 3.1 b) de la L. O. 10/2007: "Se inscribirán en la base de datos policial de identificadores obtenidos a partir del ADN lo siguientes datos: ...Los patrones identificativos obtenidos en los procedimientos de identificación de restos cadavéricos o de averiguación de personas desaparecidas".

${ }^{12}$ En relación a este tema resulta capital la Sentencia del Tribunal Europeo de Derechos Humanos de 4 de diciembre de 2008 en la que se condena a Reino Unido por considerar que es el único Estado Miembro que autoriza expresamente la conservación sistemática y por un plazo ilimitado perfiles de ADN y muestras celulares de personas que se hayan beneficiado de una absolución o una renuncia de acciones. Al tiempo sienta, con carácter general, las bases y los principios que deben regir en esta materia para salvaguardar los restantes derechos en conflicto.

V., un estudio detenido sobre esta Sentencia y la doctrina que sienta en SANZ HERMIDA, A., Notas de Derecho Procesal Angloamericano, Revista General del Derecho, 18, 2009. 
de la parte no codificante del ADN y no contendrán datos que permitan identificar directamente al interesado.

En el art. 3 se permite expresamente, de conformidad con lo dispuesto en el Derecho interno del Estado miembro requirente, y para los fines de persecución de delitos, la consulta automatizada de los perfiles de ADN. Si en el curso de una consulta automatizada se comprueba la concordancia entre un perfil de ADN transmitido y perfiles de ADN almacenados en el fichero consultado del Estado miembro receptor, el punto de contacto nacional del Estado miembro que efectúa la consulta recibirá de forma automatizada el índice de referencia con el que se haya producido la concordancia. Si no se encuentra concordancia alguna, este hecho se comunicará de forma automatizada.

Otras consideraciones dignas de interés se contienen en los arts. 4, 5, 6 y 7 de la Decisión-Marco 2008/615, referidos, respectivamente, a la transmisión de otros datos de carácter personal y de otras informaciones, al punto de contacto nacional y medidas de ejecución y, finalmente, a la obtención de material genético y transmisión de perfiles de ADN.

Concretamente, en lo que respecta al tema de la coerción jurídica y enlazando con lo dicho anteriormente en relación a la previsión de tal posibilidad prevista en la Ley Orgánica 10/2007, de 8 de octubre, el art. 4 contempla la posibilidad de comparación automatizada de perfiles de ADN y establece al efecto que los Estados miembros llevarán a cabo, de mutuo acuerdo y a través de punto de contacto nacionales, comparaciones de los perfiles de ADN no identificados con los perfiles de ADN contenidos en los perfiles de referencia de los demás ficheros nacionales de análisis de $\mathrm{ADN}$, para los fines de persecución de delitos, lo que tendrá lugar únicamente en los casos en los que se prevea dicha transmisión en el Derecho interno del Estado miembro requirente.

En nuestro Derecho, el Instrumento de ratificación del Convenio relativo a la profundización de la cooperación transfronteriza, en particular, en materia de terrorismo, delincuencia tranfronteriza y migración ilegal, hecho en Prüm el 27 de mayo de 2005, otorga plena validez a tal previsión.

A la vista de la regulación sumariamente expuesta, quisiéramos concluir manifestando que la parca e insuficiente regulación habida en España en materia de intervenciones corporales hasta el momento, debida fundamentalmente al miedo del legislador español a la hora de enfrentarse a las consecuencias de disponer de información sensible de los sujetos pasivos de las mismas. Tales recelos deben superarse y abordar de una manera clara y concisa los términos de la misma, puesto que la regulación a nivel europeo y la posibilidad de obtener los perfiles genéticos mediante comunicación transnacional de datos entre los Estados miembros, nos obliga a ello.

En efecto, en el art. 7 de la Decisión-Marco 2008/615 JAI se dice expresamente que en el caso de que en el curso de una investigación o proceso penal no se disponga del perfil de ADN de una persona determinada que se encuentre en el territorio de un 
Estado miembro requerido, este último deberá prestar asistencia judicial mediante la obtención y el análisis del material genético de dicha persona y la transmisión del perfil de $\mathrm{ADN}$ resultante, siempre que:

a) el Estado miembro requirente comunique el fin para el que se requiere;

b) el Estado miembro requirente presente una orden o declaración de investigación de la autoridad competente, exigible con arreglo a su Derecho interno, de la que se desprenda que se cumplirían los requisitos para la obtención y análisis de material genético si esa persona concreta se encontrara en el territorio del Estado miembro requirente, $y$,

c) se cumplan los requisitos para la obtención y análisis de material genético y para la transmisión del perfil de ADN obtenido con arreglo al Derecho del Estado miembro requerido.

Es evidente que las dudas que suscita la regulación actual del art. 363 LECrim. en lo que respecta al recurso a la coerción física ante la ausencia del consentimiento del sujeto pasivo de la medida, deben despejarse para adaptar nuestra regulación a las exigencias de claridad que la normativa europea demanda.

\section{LA PRUEBA DE ADN: EFICACIA Y VALORACIÓN PROBATORIA}

\section{EFICACIA}

La parca regulación en la materia no es óbice para que en la práctica diaria se admitan pruebas de identificación genética en el proceso penal, si bien, su admisión debe condicionarse, como hemos visto, al sometimiento voluntario a la previa intervención corporal ${ }^{13}$.

Asimismo, como ya se ha comentado, la actitud renuente al sometimiento voluntario a tales pruebas se considera por algunos tribunales como un indicio en su contra, incapaz por sí solo de desvirtuar la presunción de inocencia, pero que, junto a otros, sí podría enervar su eficacia, o bien un posible delito de desobediencia grave a la autoridad judicial

En este sentido, me manifiesto claramente partidaria del recurso a la coerción física, con respeto en todo caso al principio de proporcionalidad y legalidad, de forma que sólo en atención a la tutela de determinados bienes jurídicos como la vida o la libertad sexual, supuesto que nos ocupa al referirnos en este trabajo particularmente a la prueba en violencia sexual, el legislador debería de permitir de forma expresa la

${ }^{13}$ Baste como referencia las SSTS de 11 de mayo de 1993 (RA 3878), de 13 de mayo de 1998 (RA 8278) y de 23 de junio de 1999 (RA 5847). 
imposición coactiva de una intervención corporal leve, en consonancia con la doctrina constitucional de la STC 207/1996, necesaria para la obtención de la muestra biológica indubitada con la que comparar el material genético dubitado hallado en la víctima o en el lugar de los hechos y, posteriormente, practicar la prueba genética. Los resultados que arroja este análisis y su interpretación avalan esta tesis, ya que, como pasamos seguidamente a exponer, su interpretación probabilística e indiciaria no vulnera el derecho a la defensa o a la presunción de inocencia del acusado ${ }^{14}$.

El principio de libertad probatoria es el que da entrada a estos medios de prueba en el proceso penal español, porque no se encuentran limitados los medios de prueba en el Ley de Enjuiciamiento Criminal, en definitiva, no se trata de una relación de numerus clausus, de manera que los órganos jurisdiccionales admitirán todos aquellos medios de prueba que sean lícitos, en la medida en que, en su obtención, no se hayan vulnerado derechos fundamentales de la persona porque, en tal supuesto, devendrían nulos de pleno derecho, por aplicación de lo dispuesto en el art. 238 LOPJ y, fundamentalmente, en el art. 11.1 de la misma norma ${ }^{15}$.

Teniendo claras estas premisas, debe considerarse no obstante la desventaja que supone la ambigüedad en la regulación sobre la materia porque, ante la falta de obligatoriedad para ordenar estas diligencias, su admisión debe condicionarse a día de hoy, tal y como hemos visto en la práctica, al libre sometimiento por parte del interesado, con lo que gran parte del potencial de estas diligencias se pierde.

En la situación actual deben considerarse las vías a través de las cuales estas diligencias y sus resultados pueden acceder al proceso penal. En tal sentido, debe partirse de la naturaleza pericial de estas diligencias para permitir su incorporación al proceso, tal y como viene siendo práctica habitual de los órganos jurisdiccionales.

Otras dudas que deben resolverse se refieren a la contradicción de la prueba que resulte de estas diligencias, contradicción que debe tener lugar en el juicio oral, siendo precisa la presencia del perito que realizó el análisis pericial en fase de instrucción, a

${ }^{14}$ Valga como ejemplo la STS de 11 de mayo de 1993 (RA 3878) en la que se apunta tal posibilidad, si bien, en esa ocasión, ante el sometimiento voluntario a tres previas extracciones sanguíneas, la negativa a la cuarta no fue tenida en cuenta al valorar la prueba de cargo. V. también, en este sentido, el auto del Juzgado número 2 de 0 Carballiño de 16 de marzo de 2.006, al que hemos hecho anteriormente referencia, en el que se acuerda la medida y se le advierte al destinatario de la misma de que se le notifique para que acceda voluntariamente a someterse a la realización de lo acordado (extracción de saliva recogida en hisopos o extracción de sangre a los efectos de obtener muestras para la determinación de su ADN), con apercibimiento expreso de posible delito de desobediencia a la autoridad judicial en caso contrario, con advertencia de la valoración que de su negativa quepa hacerse en relación con los indicios ya existentes.

Sobre esta cuestión v. mi obra Investigación penal..., op. cit., págs. 102-126.

15 El art. 287 de la LEC consagra nuevamente esta regla, considerando al efecto que "cuando alguna de las partes entendiera que en la obtención u origen de alguna prueba admitida se han vulnerado derechos fundamentales habrá de alegarlo de inmediato con traslado, en su caso, a las demás partes...". 
efectos de considerar su posible validez probatoria, y, al fin y a la postre, su adecuada interpretación por parte del órgano jurisdiccional decisor.

Los temas relacionados, de los que se trata seguidamente, son temas clave de la disciplina y que, obviamente, se traen a colación en relación a las medidas de intervención corporal sin ánimo de exhaustividad, sino simplemente, en la medida en que se necesitan para procurar decisiones y ofrecer soluciones a los problemas que la incorporación al proceso del resultado de tales diligencias suscita.

\subsection{Recogida de Fuentes de Prueba y Actividad Probatoria}

Las actividades encaminadas a la práctica de intervenciones corporales tienen como finalidad, normalmente, la obtención de muestras biológicas del sospechoso que sometidas al pertinente análisis pericial serán incorporadas al proceso penal, como término de comparación de las muestras dubitadas obtenidas del lugar de los hechos por parte de la policía o de la exploración efectuada a la víctima de una agresión sexual ${ }^{16}$.

Tales actuaciones tienen lugar en una primera fase proceso penal, si bien, en ocasiones ni siquiera se habrá iniciado un proceso, supuesto en el cual, resulta fundamental su apertura, para que, posteriormente, se proceda en el sentido de autorizar esta medida de intervención corporal, dentro ya de la fase de instrucción, siempre que concurran indicios serios en contra del sujeto pasivo de estas diligencias y se respete la regla de la proporcionalidad de los sacrificios en su ejecución ${ }^{17}$.

Todo lo dicho apunta en el sentido de considerar que se trata de diligencias en las que el juez instructor, o incluso la policía judicial actuando a prevención obtienen y

${ }^{16}$ Sobre la recogida de muestras y vestigios del lugar de los hechos v. art. 326 LECrim. según el cual "cuando el delito que se persiga haya dejado vestigios o pruebas materiales de su perpetración, el Juez instructor o el que haga sus veces los recogerá y conservará para el juicio oral si fuere posible, procediendo al efecto a la inspección ocular y a la descripción de todo aquello que pueda tener relación con la existencia y naturaleza del hecho.

A este fin habrá de consignar en los autos la descripción del lugar del delito, el sitio y estado en que se hallen los objetos que en él se encuentren, los accidentes del terreno o situación de las habitaciones, y todos los demás detalles que puedan utilizarse, tanto para la acusación como para la defensa.

Cuando se pusiera de manifiesto la existencia de huellas o vestigios cuyo análisis biológico pudiera contribuir al esclarecimiento del hecho investigado, el Juez de instrucción adoptará u ordenará a la Policía Judicial o al médico forense que adopte las medidas necesarias para que la recogida, custodia y examen de aquellas muestras se verifique en condiciones que garanticen su autenticidad, sin perjuicio de lo establecido en el art. 282 LECrim.".

Este último precepto por su parte establece que "la Policía Judicial tiene por objeto, y será obligación de todos los que la componen, averiguar los delitos públicos que se cometieren en su territorio o demarcación; practicar, según sus atribuciones, las diligencias necesarias para comprobarlos y descubrir a los delincuentes, y recoger todos los efectos, instrumentos o pruebas del delito de cuya desaparición hubiera peligro, poniéndolos a disposición de la autoridad judicial...”.

${ }^{17} \mathrm{Si}$ se quiere profundizar más en esta cuestión sobre la naturaleza de las diligencias llevadas a cabo en la fase de instrucción y su validez como medios de prueba anticipada o preconstituida, v. mi trabajo sobre Investigación penal..., op. cit. 
aseguran fuentes de prueba, a partir de las cuales tendrá lugar, en su caso, la pertinente actividad probatoria ${ }^{18}$.

Pero dada la especificidad de la materia que estamos tratando, nuestra atención se centrará más bien en la eficacia y valoración que debe referirse a la prueba realizada a partir de los vestigios o muestras biológicas obtenidas del sujeto pasivo de la intervención corporal, contrastadas con las muestras dubitadas recogidas del lugar de los hechos por parte de la policía científica o de la propia víctima.

\subsection{Requisitos Técnicos}

$\mathrm{Al}$ margen de las anteriores consideraciones, relativas más bien al modo en el que debe procurarse la introducción en el juicio del resultado de la intervención corporal, para dotar de fiabilidad a estas diligencias, deben tenerse en cuenta una serie de garantías que se refieren fundamentalmente a la observancia de la denominada "cadena de custodia".

En este sentido la labor del Secretario Judicial resulta esencial, de modo que en su función de ejercer la fe pública debe proceder a dejar constancia de que la muestra recogida, enviada y analizada es la que debía ser. Esta cadena debe quedar reflejada a través de diligencias de remisión y de copias de oficios en la documentación del sumario.

Los pasos que deben seguirse son los siguientes:

1. Recogida de muestras siguiendo las reglas de la lex $\operatorname{artis}^{19}$, identificándolas correctamente, y con citación de las partes personadas si existen y ello no perjudica a la investigación, levantándose acta por el Secretario Judicial. Esta acta debe estar firmada por el juez y las demás personas presentes ${ }^{20}$.

Por lo tanto, la recogida de muestras de personas vivas ha de hacerse con respeto absoluto a las reglas de la lex artis. Por ejemplo, para la recogida de una muestra de sangre hay dos sistemas: la venoclisis o punción venosa y la

${ }^{18}$ La diferencia de las diligencias de prueba con los actos instructorios radica esencialmente en su finalidad y virtualidad ya que sólo las primeras resultan aptas para desvirtuar la presunción de inocencia, de manera que el órgano de enjuiciamiento pueda fundamentar una sentencia condenatoria en contra del acusado en tales diligencias de naturaleza probatoria.

${ }^{19}$ En este sentido deben tenerse en cuenta las prevenciones para una adecuada recogida de muestras, evitando la posible contaminación química o biológica que desvirtuaría los resultados, hasta convertirlos en inútiles.

${ }^{20}$ Recordemos que debe tenerse muy presente en esta materia el sentimiento de pudor de la persona afectada, salvaguardando convenientemente su derecho a la intimidad personal, con la presencia, en su caso, de una persona de su confianza y, por aplicación del principio de proporcionalidad, restringiendo en la medida de lo posible los efectos lesivos para la intimidad de la persona, limitando al mínimo el número de personas intervinientes o que presencien la intervención corporal. 
punción dactilar. El primero permite obtener un mínimo de 10 a $20 \mathrm{ml}$. de sangre y debe realizarse en jeringas o tubos que contengan EDTA como anticoagulante y este método es idóneo cuando se necesite "mucho" ADN para realizar análisis en el laboratorio. El segundo sistema es menos invasivo y menos doloroso para el sujeto pasivo y consiste en que se pinche el dedo en la cara anterior y se deja que salgan algunas gotas de sangre que pueden depositarse o dejarse secar en una gasa, algodón, papel secante...

En todo caso, no se trata de relacionar a continuación las técnicas para realizar las intervenciones corporales porque por su heterogeneidad resultaría un trabajo ingente y que además se escapa de la materia objeto de estudio. Pero es indudable que la presencia de un perito a instancia de la parte y la constancia escrita de todas estas circunstancias resultarán esenciales a la hora de valorar los resultados obtenidos, razón por la cual se pone especial énfasis en esta primera condición para dotar de validez a estas pruebas.

2. Una vez obtenidas las muestras debe procederse a su remisión por un medio seguro, debiendo acompañarse la muestra de un oficio que refleje toda la muestra enviada que debe ser comprobada antes de firmar el acuse de recibo, de manera que haya identidad entre la muestra enviada y la que se recibe.

3. Recibidas las muestras en el Laboratorio, se debe realizar el Informe, y en él se deben hacer constar las muestras recibidas y que se someten a examen, con vistas a que quede constancia documental de todas estas cuestiones ${ }^{21}$.

4. Elaboración del correspondiente dictamen, posterior al reconocimiento y análisis de las muestras, el cual será el punto de referencia esencial a la hora de proceder a la valoración de los resultados obtenidos y que en él se $\operatorname{plasman}^{22}$.

Si se observan estas garantías en la ejecución de la intervención corporal y posterior remisión al órgano encargado de su análisis, difícilmente se pueden plantear situaciones en las que resulte conveniente realizar una segunda prueba a efectos de contraste.

De todos modos, si la defensa lo solicita no debiera haber ningún obstáculo, antes al contrario, para que sea posible su realización, si bien, con la posibilidad, de proceder a su contradicción en la fase sumarial y, posteriormente, en la fase de juicio oral. Por ello,

${ }^{21}$ El que sean laboratorios especialmente acreditados y que utilicen técnicas homologadas o el mismo protocolo en torno a la metodología y a los patrones a utilizar, son cuestiones de las que ya nos hemos ocupado en el capítulo primero de este trabajo. A ello nos remitimos.

${ }^{22}$ FABREGA RUIZ, C. F., Aspectos jurídicos de las nuevas técnicas de investigación criminal, con especial referencia a la "huella genética" y su valoración judicial, "La Ley", núm. 4721, págs. 3-4. 
rara vez tendrá virtualidad práctica un segundo análisis, razón por la cual resulta más conveniente favorecer la contradicción, permitiendo que el juez adquiera su convencimiento sobre la base de un interrogatorio cruzado entre las partes y los peritos ${ }^{23}$.

Se trata de una solución residual pensada para supuestos en que el dictamen pericial necesite ser contrastado porque los resultados que arroja, por la razón que sea, resultan cuestionables, lo que, si la pericia se desarrolla correctamente y según el método adecuado, observando en todo momento la cadena de custodia, en principio, no tiene por qué suceder ${ }^{24}$. Por ello, resulta más conveniente que el reconocimiento e informe se realice por el perito de la acusación, normalmente en la fase de instrucción, respetando las reglas de la lex artis, y, siendo sometido a contradicción en ese momento, y posteriormente, en el debate a que dé lugar el juicio oral, lo que permitará, en su caso, sustentar la tesis de la defensa.

\subsection{Requisitos Legales: La Prueba Prohibida}

Las intervenciones corporales deben reunir en su práctica una serie de requisitos y presupuestos, de los que ya se ha tratado, cuya ausencia determinará la nulidad de lo actual y la ausencia de efectos probatorios de esas diligencias. Esto es así por aplicación de lo dispuesto en el art. 11.1 LOPJ que establece que «no surtirán efecto las pruebas obtenidas, directa o indirectamente, violentando los derechos o libertades fundamentales».

Puede decirse que este es el precepto fundamental y de referencia en tema de prueba ilícita y el que, en su comentario, le ha llevado a la jurisprudencia a establecer una doctrina consolidada de lo que debe entenderse por prueba ilícita o prueba prohibida ${ }^{25}$.

${ }^{23}$ Tendrá sentido, por ejemplo, en aquellas situaciones en que ha habido contaminación biológica o química, o en aquellas situaciones en que la muestra de ADN estaba muy deteriorada y los resultados puedan ser relativos, pero, con carácter general, el resultado no planteará duda y los términos del debate deben más bien referirse a su valoración y eficacia en relación con los hechos y con las restantes pruebas.

${ }^{24}$ Así lo reconoce LORENTE ACOSTA/LORENTE ACOSTA (El ADN y la identificación en la investigación criminal y en la paternidad biológica, Granada, 1995, págs. 195 y ss.) que concluye que el "recurso sistemático al contraperitaje es poco aconsejable en los análisis con ADN ya que, salvo error grosero por parte del Laboratorio, las características de las técnicas empleadas permiten pocas dudas: si a una persona se le excluye, normalmente no queda ninguna duda; si por el contrario, existe una inclusión (se concluye que un indicio " $X$ " proviene de una persona " $X$ "), han de buscarse siempre los resultados estadísticos, para ver la probabilidad de inclusión que se consigue. Existen pocos supuestos en los que la poca cantidad de la muestra o la mala calidad de la misma (ADN muy degradado) no permite al laboratorio obtener probabilidades de inclusión muy altas (al menos mayores al 99\%, o uno de cada cien), por lo que en estos supuesto puede quedar una duda razonable".

${ }^{25}$ Tal y como pone de relieve MIRANDA ESTRAMPES (El concepto de prueba ilícita y su tratamiento en el proceso penal, Barcelona, 1999, págs. 15 y ss.) aunque el concepto de prueba ilícita no es uniforme en la doctrina ni en la jurisprudencia, parece conveniente conceptuarla como "no sólo aquella en cuya obtención o práctica se han violentado derechos fundamentales, sino también aquella que ha sido obtenida con infracción de la legalidad procesal ordinaria". 
En tal sentido, el punto de partida no es otro que la necesaria observancia en la obtención de cualquier fuente de la prueba de una serie de garantías que, en definitiva, no son más que un medio de respetar los derechos y libertades de los sujetos que se ven afectados por tales actuaciones.

De lo que se trata es de evitar que el ejercicio del ius puniendi del Estado se realice a cualquier precio, lo que se traduce en la ineficacia de los medios de investigación y de prueba lesivos de derechos fundamentales de la persona, tanto si tal lesión ha dado lugar a un medio de prueba directo como indirecto.

Estrictamente para que se pueda hablar de ilicitud probatoria es necesario que además de menoscabar un derecho fundamental con motivo de esa actividad probatoria, exista un nexo de causalidad entre ambos, de manera que la obtención de la fuente de prueba sea el resultado de lesionar el derecho fundamental. Y es precisamente en la fase de investigación en la que tienen normalmente lugar esas actuaciones porque, esas lesiones de derechos fundamentales se producen con motivo de actos extraprocesales, lo que no impide que esta violación ocurra también con posterioridad a lo largo del desarrollo del juicio, aunque no sea lo más usual.

Pero siguiendo a DÍAZ CABIALE y a MARTÍN MORALES, debe distinguirse la prueba ilícita de la violación de principios que rigen la actividad probatoria, supuestos en los que no hay propiamente una prueba ilícitamente obtenida. Ante tales situaciones, como reconoció la STC 64/1986, el ordenamiento jurídico no puede permanecer indiferente, pero para denunciar estas situaciones debe acudirse a las causas de nulidad previstas en los art. 238 a 243 LOPJ y el 225.3 de la nueva Ley de Enjuiciamiento Civil, de manera que en estos supuestos no se hablaría de prueba ilícita, sino de privación de eficacia en los términos que contempla el art. 238 LOPJ y el art. 225 de la nueva LEC. En conclusión, "es imprescindible dejar fuera del concepto de ilicitud probatoria cualquier infracción del ordenamiento jurídico en materia probatoria que no provoque la obtención de la fuente o medio de prueba", doctrina que resulta de la aplicación de lo dispuesto en la STC 64/1986, de 21 de mayo.

En la materia objeto de comentario, se trata, dicho sucintamente, que tal medida se haya previsto por una ley, con una autorización judicial expresa, y con una restricción proporcionada de los derechos y libertades en juego, sin lesionar, en ningún caso, la vida o la salud del sujeto objeto de tal intervención o registro corporal realizada para la obtención de una mínima muestra de su material biológico.

La sanción que establece la ley no es otra que decretar la nulidad de lo actuado, de manera que no será posible utilizar esa prueba o cualquier otra que tenga su origen en ella, como medio de enervar la presunción de inocencia del acusado en ese proceso, porque, en definitiva, es un medio de preservar la presunción de inocencia.

No obstante, la última jurisprudencia tiende a matizar este criterio, en el sentido de explicar la ineficacia de las pruebas obtenidas ilícitamente en la lesión del derecho al proceso con todas las garantías del art. 24.2 CE y al principio de igualdad de armas, 
de manera que la valoración de un medio de prueba obtenido ilícitamente lesionaría, en primer término, el derecho al proceso debido y, si además tales pruebas son las únicas que fundamentan una sentencia condenatoria en su contra, la presunción de inocencia; cosa que no sucedería si tal condena se basase en otros medios de prueba válidos e independientes ${ }^{26}$.

La teoría de la "fuente independiente" se introdujo por primera vez en nuestro Derecho por medio del art. 11.1 LOPJ y, posteriormente, obtuvo reconocimiento jurisprudencial, sobre todo a raíz de la STC 86/1995, de 6 de junio, si bien, el Tribunal Supremo ya había hecho uso de ella con anterioridad ${ }^{27}$. Esta línea argumental es la que discurre a lo largo de la STC 81/1998 que completa la doctrina sentada por el Tribunal Constitucional sobre la prueba ilícita hasta el momento ${ }^{28}$.

Añade a su anterior doctrina que la invalidez de las pruebas reflejas sobreviene como consecuencia de la existencia de una "conexión de antijuridicidad", es decir, de una relación entre ambos medios de prueba lo suficientemente fuerte para estimar que la ilicitud originaria de las primeras trasciende a las segundas, hasta el punto de provocar la sanción invalidante ${ }^{29}$.

${ }^{26}$ DÍAZ CABIALE, J. A., MARTÍN MORALES, R., La garantía constitucional de la inadmisión de la prueba ilícitamente obtenida, Madrid, 2001, págs. 22-33.

El origen de esta doctrina se encuentra en la STC 81/1998, refrendada por las SSTC 49/1999, 94/1999, 139/1999, 161/1999, 166/199, 171/1999, 238/1999, 239/1999, 8/2000, 50/2000, 126/2000, 127/2000 y $299 / 2000$.

${ }^{27}$ En esta sentencia se le dio validez a la declaración del acusado emitida en el momento del juicio oral, considerando que se estaba en presencia de una fuente independiente de prueba que puede ser admitida y valorada, ya que, desde que se produjo la actuación ilícita había transcurrido un cierto tiempo y, desde entonces, el acusado había recibido asesoramiento legal, había podido evaluar sus posibilidades de defensa y, si se había producido su valoración lo había sido tras haber sido advertido de que no tenía obligación de hacerlo, es decir, siendo plenamente consciente de que sus manifestaciones podrían ser utilizadas en su contra.

${ }^{28}$ Comentarios a esta resolución se pueden v. en JUANES PECES, A., La prueba prohibida. Análisis de la sentencia 81/1998 del Tribunal Constitucional. Un nuevo enfoque de la presunción de inocencia, AJA, 30 de julio de 1998, núm. 353, págs. 1-5; LÓPEZ ORTEGA, J. J., Prueba y proceso penal. El alcance derivado de la prueba ilícita en la jurisprudencia constitucional (A propósito de la STC 81/1998), "Derecho y Proceso penal”, 1999, núm. 1, págs. 123 y ss.; MARTÍ SÁNCHEZ, N., La llamada "prueba ilícita” y sus consecuencias procesales, AP, 19998, t. I., núm. 7, págs. 141-162.

${ }^{29}$ En el supuesto concreto al que se refiere este pronunciamiento, "para determinar si esa conexión de antijuridicidad existe o no hemos de analizar, en primer término, la índole y características de la vulneración del derecho al secreto de las comunicaciones materializadas en la prueba originaria, así como su resultado, con el fin de determinar si, desde el punto de vista interno, su inconstitucionalidad se transmite o no a la prueba obtenida por derivación de aquella... Desde el punto de vista de la índole y características de la vulneración que aquí se trata ha de considerarse, en primer término, cuál de las garantías de la injerencia en el derecho al secreto de las comunicaciones telefónicas ha sido efectivamente menoscabada y en qué forma...Esto sentado, procede analizar el resultado inmediato de la infracción, esto es, el conocimiento obtenido a través de la injerencia practicada inconstitucionalmente. La sentencia impugnada subraya que, en virtud de la intervención telefónica, sólo se obtuvo un dato neutro... A partir de ese hecho, el Tribunal Supremo entiende que dadas las circunstancias del caso y, especialmente, la observación y seguimiento de que el recurrente era objeto, las sospechas que recaían contra él y 
El Tribunal Constitucional lo que pretende con su pronunciamiento es reducir el contenido de la garantía de la exclusión de la prueba ilícita y para ello construye la teoría de la conexión de antijuridicidad. Pero sin llegar al extremo de negar esta garantía, por lo que debe determinar los supuestos en que las pruebas indirectas, por ser independientes jurídicamente, pueden ser admitidas.

Se aprecia la recepción en nuestro Derecho de una serie de teorías norteamericanas que han supuesto excepciones a la aplicación de la doctrina de "the fruit of the poisonous tree doctrine".

En tal sentido, según la teoría de la fuente independiente de lo que se trata es de que la prueba que se presenta no sea consecuencia de la lesión de un derecho fundamental, siendo ésta la única vía que la dicción literal del art. 11.1 LOPJ permite, ya que, al prohibir absolutamente la valoración de las pruebas ilícitas, sin excepción alguna, es preciso para dar validez a alguna de estas pruebas, que exista una desconexión causal entre la prueba indirecta y la lesión del derecho fundamental, o si se prefiere, será válida siempre que los hechos pueden alcanzarse a través de una fuente independiente.

La tesis del nexo causal atenuado supone que la prueba no se habría obtenido de no producirse la lesión del derecho fundamental, pero existe una cierta diferenciación entre la lesión del derecho y la obtención de la prueba derivada, razón por la cual se rompe la conexión entre la prueba ilícita inicial y el acto independiente posterior. La crítica a la aceptación de esta teoría es fácil, la dicción literal del art. 11.1 LOPJ impide cualquier posible valoración de la prueba obtenida violentando, "directa o indirectamente", derechos fundamentales de la persona. No obstante, el Tribunal Constitucional la admite considerando que se trata de una prueba que no guarda relación con la lesión del derecho fundamental.

Por último, la STC 81/1998 supuso la importación definitiva de la teoría del descubrimiento inevitable, y que ha desembocado en el reconocimiento de la teoría de la "conexión de antijuridicidad". Se trata de distinguir entre la prueba obtenida violando derechos fundamentales y la prueba que se habría obtenido, hipotéticamente, sin esa vulneración (DÍAZ CABIALE, MARTÍN MORALES, p. 88 y ss. y 110).

Lo que es evidente es que en nuestro sistema, al igual que sucede en el modelo norteamericano, se busca la disuasión policial al negarle validez a las pruebas obtenidas

\footnotetext{
la irrelevancia de los datos obtenidos a través de la intervención telefónica, el conocimiento derivado de la injerencia en el derecho fundamental contraria a la Constitución no fue indispensable ni determinante por sí solo de la ocupación de la droga o, lo que es lo mismo, que esa ocupación se hubiera obtenido, también, razonablemente, sin la vulneración del derecho. Esta afirmación que, desde la perspectiva jurídica que ahora estamos considerando rompe, según la apreciación del Tribunal Supremo, el nexo entre la prueba originaria y la derivada, no es, en sí misma un hecho, sino un juicio de experiencia acerca del grado de conexión que determina la pertinencia o impertinencia de la prueba cuestionada. Por consiguiente, no se haya exento de nuestro control, pero, dado que, en principio, corresponde a los jueces y tribunales ordinarios, el examen de este Tribunal ha de ceñirse a la comprobación de la razonabilidad del mismo". LÓPEZ ORTEGA, J. J., Prueba y proceso penal.., op. cit., págs. 123 y ss.
} 
violentando derechos fundamentales de la persona. Pero, además, en nuestro Derecho la perspectiva debe ser también constitucional. Es decir, se trata de defender el modelo constitucional del proceso, al tiempo que con ello se evitan actuaciones policiales abusivas para los ciudadanos.

A modo de ejemplo, si resulta afectado el derecho a la intimidad personal y corporal en los términos que refleja el art. $18 \mathrm{CE} \mathrm{o} \mathrm{el} \mathrm{derecho} \mathrm{a} \mathrm{la} \mathrm{integridad} \mathrm{física} \mathrm{del}$ art. 15 del mismo texto legal, sin mediar consentimiento del sujeto pasivo de la medida de intervención corporal, nuevamente se trataría, a falta de regulación precisa que autorice la intervención corporal coactiva, de una diligencia de intervención corporal nula por resultar ilícita y atentatoria contra tales derechos fundamentales.

El resultado derivado de la práctica y obtención de un medio de prueba ilícito no es otro que la absoluta nulidad e ineficacia de lo practicado. Para hacer valer tal ilicitud en el proceso penal, nuevamente nos encontramos, prácticamente, huérfanos de regulación.

Una vez más debe partirse del art. 11.1 LOPJ, que simplemente dice que tales pruebas «no surtirán efecto». La práctica forense difiere el examen de la licitud o ilicitud de la prueba al momento de dictar sentencia, si bien, como afirma MIRANDA ESTRAMPES, no debe haber inconveniente, sino que, por el contrario, parece conveniente que el órgano judicial rechace las pruebas obtenidas ilícitamente con anterioridad, por ejemplo, en el trámite de admisión de la prueba, con la finalidad de evitar de este modo la influencia psicológica de la prueba prohibida en el juzgador ${ }^{30}$.

Sin embargo, la solución más deseable sería la consagrada en el art. 287.1 de la nueva Ley de Enjuiciamiento Civil, en el que se dice expresamente que "cuando alguna de las partes entendiera que en la obtención u origen de alguna prueba admitida se han vulnerado derechos fundamentales habrá de alegarlo de inmediato, con traslado, en su caso, a las demás partes. Sobre esta cuestión, que también podrá ser suscitada de oficio por el tribunal, se resolverá en el acto del juicio o, si se tratare de juicios verbales, al comienzo de la vista, antes de que dé comienzo la práctica de la prueba. A tal efecto, se oirá a las partes y, en su caso, se practicarán las pruebas pertinentes y útiles que se propongan en el acto sobre el concreto extremo de la referida ilicitud".

De esta manera se estaría posibilitando la contradicción al inicio de las sesiones del juicio oral sobre una cuestión de extrema importancia en la que resulta esencial, no sólo

${ }^{30}$ En apoyo de esta tesis MIRANDA ESTRAMPES (El concepto de prueba ilícita y su tratamiento en el proceso penal, Barcelona, 1999, págs. 995 y ss.) cita la jurisprudencia del Tribunal Constitucional que, con referencia a la interpretación de la expresión y concepto de pertinencia de la prueba (arts. 659 y 792.1 LECrim.) dice que "el concepto de "medios de prueba pertinentes" que aparece en el art. 24.2 de la Constitución pasa, así, a incorporarse, sobre su contenido esencialmente técnico-procesal, un alcance también sustantivo, en mérito del cual nunca podrá considerarse "pertinente" un instrumento probatorio así obtenido" (STC 114/1984, de 29 de noviembre). Con todo, este autor entiende que esta solución debe ser provisional, en tanto no se contemple expresamente la inadmisión de las pruebas ilícitamente obtenidas, ya que, en pura técnica procesal, el concepto de pertinencia poco o nada tiene que ver con la licitud o ilicitud de la prueba. 
la posibilidad de hacer alegaciones sobre la cuestión, sino también de practicar prueba, resolviéndose en este momento inicial, sin necesidad de esperar al momento de dictar sentencia. No obstante, el órgano que debe conocer y resolver sobre la posible ilicitud probatoria es el mismo que debe decidir sobre el fondo del asunto, por lo que no se evita con ello la posible influencia psicológica de estas pruebas ilícitas en el juzgador ${ }^{31}$.

Además, esta solución por arriesgada debe ser considerada por el momento como una mera hipótesis, al fin y al cabo, trasladar soluciones del proceso civil cuando hay un régimen jurídico específico en el proceso penal resulta, cuando menos, cuestionable. Deben pues considerarse primero las opciones que permite actualmente la Ley de Enjuiciamiento Criminal.

En primer lugar, debe considerarse el control de la ilicitud probatoria como una cuestión que no debe quedar únicamente en poder de las partes del proceso, de manera que el órgano jurisdiccional también, no sólo pueda, sino que deba controlar de oficio esta cuestión.

En contra de esta posibilidad, se alegaba el tenor literal del art. 793.2 LECrim. (hoy, 786.2 LECrim., en términos idénticos, salvedad hecha de la expresa denegación de recurso frente a tal decisión, sin perjuicio de la pertinente protesta y de que la cuestión pueda ser reproducida, en su caso, en el recurso frente a la sentencia), que regulaba la audiencia saneadora del proceso abreviado, en los siguientes términos «El juicio oral comenzará con la lectura de los escritos de acusación y de defensa. Seguidamente, a instancia de parte, el juez o tribunal abrirá un turno de intervenciones para que puedan las partes exponer lo que estimen oportuno acerca de la competencia del órgano judicial, vulneración de algún derecho fundamental, existencia de artículos de previo pronunciamiento, causas de suspensión del juicio oral, así como sobre el contenido y finalidad de las pruebas propuestas o que se propongan para practicarse en el acto. El juez o tribunal resolverá en el mismo acto lo procedente sobre las cuestiones planteadas» ${ }^{32}$.

${ }^{31}$ En este sentido parecía pronunciarse, si bien, sin referirse a la entonces futura Ley de Enjuiciamiento Civil, MIRANDA ESTRAMPES (El concepto de prueba ilícita..., op. cit., págs. 97-98), valorando muy positivamente esta hipotética solución.

Con la Ley de Enjuiciamiento Civil la solución ya no resulta tan hipotética partiendo de la vocación universalidad con la que nace y reconoce expresamente la Exposición de motivos cuando dice que "en coincidencia con anteriores iniciativas la nueva Ley de Enjuiciamiento Civil aspira también a ser Ley procesal común, para lo que, a la vez, se pretende que la vigente Ley Orgánica del Poder Judicial, de 1.985, circunscriba su contenido a lo que indica su denominación y se ajuste, por otra parte, a lo que señala el apartado primero del art. 122 de la Constitución. La referencia en este precepto "al funcionamiento" de los Juzgados y Tribunales no puede entenderse, y nunca se ha entendido, ni por el legislador postconstitucional ni por la jurisprudencia y la doctrina, como referencia a las normas procesales que, en cambio, se mencionan en otros preceptos constitucionales....". A mayor abundamiento, el art. 287 de la nueva LEC pertenece al capítulo V referido a las "disposiciones generales sobre la prueba".

${ }^{32}$ Redacción dada por la Ley de 13 de noviembre de 2009 de reforma de la legislación procesal para la implantación de la nueva oficina judicial. 
Sin embargo, debe entenderse que, como afirmaba MIRANDA ESTRAMPES, la dicción literal de este precepto no era obstáculo para que el juez pudiese apreciar de oficio la ilicitud probatoria. No es lo mismo condicionar la apertura de la audiencia saneadora a la existencia de una petición de parte interesada, a que el control de la licitud de la prueba sea necesariamente siempre a instancia de parte (MIRANDA ESTRAMPES, 1999, p. 123-124).

Resuelta esta primera duda, queda pendiente el tema del momento procesal oportuno para denunciar la ilicitud. En tal sentido, debe partirse nuevamente de la opción manifestada ya en torno a la conveniencia de evitar la influencia psicológica del juzgador por parte de la prueba obtenida con violación de derechos fundamentales de la persona.

En primer lugar, nada impide que en la fase de instrucción se pueda hacer valer tal ilicitud. Es en el momento en que se está llevando a cabo una actividad investigadora y aseguratoria de las fuentes de prueba, cuando el órgano jurisdiccional debe observar escrupulosamente el procedimiento y considerar que los restantes órganos o personas intervinientes en el mismo así lo han hecho. En caso contrario, deberá ser consecuente declarando la ilicitud de la prueba así obtenida. Sino fuera así, ello podría dar lugar a la apertura del juicio oral basada en datos nulos carentes de fuerza incriminatoria, siguiéndose innecesariamente un proceso contra una persona que deberá soportarlo injustamente. De otro lado, será mejor depurar la ilicitud probatoria cuanto antes, sino queremos correr el riesgo de la "contaminación" a la que de otro modo estarían sometidas otras pruebas derivadas, directa o indirectamente, de esa actuación ilícita.

Esta posibilidad es particularmente interesante en relación al tema de las medidas de intervención corporal que, como hemos visto, se configuran normalmente como medios de prueba anticipada o preconstituida, según los casos, que tienen lugar y se adoptan, normalmente, en la fase de instrucción.

Sin embargo, el problema principal estriba en el hecho de que será el propio órgano instructor que acordó la diligencia el que deba declarar su ilicitud. Su imparcialidad y neutralidad, fuera de toda duda, permitirán, al menos tal dualidad, pero, no deja de ser comprometido para el órgano jurisdiccional controlar de oficio su propia actuación, por lo que para corregir las posibles deficiencias que esta situación pueda generar, resulta esencial que el Ministerio Fiscal asuma un papel activo, controlando la posible ilicitud de las diligencias que se lleven a cabo. Ello es particularmente interesante en aquellas situaciones en que se haya decretado el secreto de sumario, debiendo combatir, sobre todo por la vía de los recursos, aquellas resoluciones limitativas de derechos fundamentales, de las que pueda derivarse una prueba, en las que, directa o indirectamente, en su obtención, se haya vulnerado alguno de estos derechos esenciales (p. 126-129). 
Ya terminada la instrucción, en el ámbito del proceso abreviado debe considerarse la audiencia saneadora regulada en los términos vistos en el art. 786.2 LECrim. ${ }^{33}$ Es en esta audiencia preliminar, que tiene lugar al inicio de las sesiones del juicio oral, donde deben concentrarse las peticiones de nulidad suscitadas, en lo que ahora nos concierne, por la violación de derechos fundamentales en el momento de obtención de una fuente de prueba en la fase de instrucción ${ }^{34}$. Y lo que debe estar fuera de toda duda es que, pese a la postura vacilante de nuestro Tribunal Supremo en este sentido (v. por ejemplo, SSTS de 6 de marzo y de 6 de octubre de 1995), esta cuestión debe resolverse inmediatamente, no quedando diferida al momento de dictar sentencia, porque entonces se podrá practicar la prueba en el momento del juicio oral, lo que no es deseable a efectos de evitar que la convicción del tribunal se forme sobre la base de la prueba obtenida ilícitamente.

Simplemente, concluir con el convencimiento de que la posibilidad que brinda este precepto no es exclusiva ni excluyente, de manera que debe considerarse también la posible denuncia y control de la prueba ilícita en la fase de instrucción, o, incluso, con posterioridad a esta audiencia preliminar, de oficio o a instancia de parte, porque la vulneración de derechos fundamentales exige tal flexibilidad.

De todos modos, lo que es evidente es que la situación actual es insatisfactoria, y parece inaplazable una reforma de la Ley de Enjuiciamiento Criminal en el sentido de arbitrar mecanismos que permitan el control, a instancia de las partes personadas en el procedimiento, de los supuestos de ilicitud probatoria, con el establecimiento de una audiencia preliminar en la que, con carácter previo, se debata sobre esta cuestión. No obstante, como hemos visto, esta solución tiene el inconveniente de que se está controlando la posible ilicitud por el órgano de enjuiciamiento, con lo que el influjo psicológico opera igualmente y que evidencia la conveniencia de que, si la ilicitud tiene lugar en la fase de instrucción, el órgano judicial que la dirija debe constatar tal ilicitud y apartar del conocimiento del órgano de enjuiciamiento tales pruebas (MIRANDA ESTRAMPES, p. 131-136).

Sino, lo que sucederá, tal y como viene siendo habitual, tanto en el proceso abreviado, en el que según hemos visto la decisión sobre la ilicitud se difiere al momento

${ }^{33}$ En la nueva redacción del proceso abreviado, reformado por la Ley 38/2002, de 24 de octubre, el artículo citado se corresponde con el art. 786.2 LECrim. que mantiene la regulación anterior en términos prácticamente idénticos. Simplemente se añade que «frente a la decisión adoptada no cabrá recurso alguno, sin perjuicio de la pertinente protesta y de que la cuestión pueda ser reproducida, en su caso, en el recurso frente a la sentencia».

${ }^{34}$ Quizá por ello la jurisprudencia (v. STS de 24 de junio de 1993) se muestra reacia a permitir el control de la ilicitud probatoria en el momento de la instrucción, salvo si se trata de situaciones de "extrema gravedad", como por ejemplo, una declaración prestada bajo tortura, nunca en otro caso. 
de dictar sentencia, pese a su planteamiento como cuestión previa ex art. 786.2 LECrim., como en el ordinario, a falta de mecanismos que permitan tal control previo, será al dictar sentencia el tribunal el que deba apreciar tal ilicitud, con la carga que ello comporta a la hora de fundamentar el fallo exclusivamente en pruebas lícitas, sin que sea tenida en cuenta, en ningún momento, la prueba ilícita o las derivadas de ella, de forma manifiesta o encubierta, en el proceso de génesis y formación de la resolución judicial que pone fin a la causa penal ${ }^{35}$.

\section{LA APRECIACIÓN DE LA PRUEBA DE ADN}

El tema de las intervenciones corporales y de los análisis genéticos conduce inexorablemente a tratar la valoración de la prueba que de ellas resulten. Hemos visto que la naturaleza pericial de estas diligencias está presente a lo largo de todo el proceso, desde el momento de su obtención, pasando por su análisis, y, finalmente, hasta el momento en el que tiene lugar la comparación y contraste con las muestras dubitadas.

Hemos analizado, en primer lugar, las garantías de deben observarse a la hora de realizar la oportuna intervención corporal, y las que deben presidir el proceso de análisis de las muestras indubitadas obtenidas del sujeto pasivo de estas diligencias, si bien, en relación a esta última cuestión nos remitimos más bien a las reglas de la lex artis, que son, en definitiva, las que aseguran la corrección de estas pruebas.

Resta, pues, por examinar el proceso de valoración del resultado de estas diligencias. Su naturaleza pericial exige que tengamos, principalmente, en cuenta las reglas de valoración de este medio de prueba. Ello determina que normalmente el juez, a la hora de valorar los análisis practicados, se encontrará huérfano de los conocimientos necesarios para valorar adecuadamente los resultados que estos arrojen. Esta situación es particularmente grave en relación a la interpretación de los resultados que proporcionen los análisis genéticos, en los que la especialidad de la materia dificulta enormemente su tarea.

No es posible, por otro lado, exigirles a los jueces este grado de especialización. De hecho, estamos a favor de que esta especialización se refiera a los peritos actuantes ante los órganos jurisdiccionales, y, recordemos, además, nuestra firme apuesta porque su intervención tenga lugar en el acto del juicio oral, aportando la debida claridad en una materia no exenta de dificultades.

Aún así, es evidente que la última palabra la tiene el juez. Lo normal será que se fíe del dictamen presentado, que si, al menos, está debidamente contrastado y aclarado

${ }^{35}$ Un estudio más detenido sobre este tema, particularmente sobre la denuncia de la ilicitud probatoria en la Ley Orgánica del Tribunal del Jurado, v. en mi trabajo Investigación penal.., op. cit., págs. 145 y ss. 
en el momento de práctica de la prueba, será un elemento muy a tener en cuenta a la hora de emitir su fallo ${ }^{36}$. Pero, si ni siquiera presenta esta nota, el juez, falto de conocimientos específicos sobre la materia, prácticamente reproducirá el informe tal y como ha sido emitido, o peor aún, tal y como ha sido presentado por la acusación y/o la defensa.

Advertimos de los peligros que las nuevas tecnologías comportan, pero no negamos con ello su virtualidad e importancia. Al contrario, simplemente, tratamos de constatar una realidad que la ley actual permite y que hay que corregir.

En ese proceso de interpretación y valoración de la prueba pericial resulta esencial y en él no se le puede exigir al juez que se convierta en un hombre de ciencia, pero sí que pueda controlar la validez de las pruebas científicas. El juez, al igual que los abogados y fiscales, debe controlar la competencia de los peritos y la corrección de la aplicación de la técnica pericial al caso concreto, la adecuada recogida de las muestras, los resultados presentados en términos de probabilidad... Y si una primera solución sería la de llamar a un perito que informase sobre estas cuestiones, ello puede tener sentido en situaciones de extrema complejidad, pero no así con carácter general. Generalmente los criterios que permiten valorar esta actuación son otros: la valoración de la autoridad científica, la incorporación al patrimonio científico comúnmente aceptado de los métodos de investigación por él seguidos y, finalmente, la coherencia lógica de su argumentación. Sobre estos tres pilares debe sentarse la valoración del juez, que, resultará después de la debida contradicción de los informes periciales presentados por acusación y defensa.

La libre valoración de la prueba que preconiza el art. 741 LECrim. no debe esgrimirse en esta materia como un medio de eludir una valoración razonada y fundamentada de los medios de prueba. De hecho, la utilización de máximas de experiencia provenientes de saberes especializados le aporta mayor rigidez al proceso de valoración que si se tratase de reglas de la sana crítica provenientes de la experiencia cotidiana. Y su vulneración podría llegar a fundamentar incluso un recurso de casación por realizar la sentencia una interpretación irracional o arbitraria, carente de motivación y que, por tanto, conculcaría la presunción de inocencia.

Sin llegar a estos extremos que nos sitúan ya en el tema del control de la motivación de la decisión judicial, debemos prestar atención al proceso anterior de formación o génesis de esa voluntad, en la que tendrán especial interés los dictámenes periciales que se presenten.

${ }^{36}$ Debe recordarse que la conveniencia de un contraanálisis se reduce a los supuestos en que la dificultad de la materia o la complejidad es tal que el resultado debe contrastarse con un segundo informe. En los demás casos, la propia dinámica del sistema, fundamentalmente, el hecho de que sea realizado por un equipo técnico y su alto precio, desaconsejan este tipo de contrapericias, teniendo en cuenta, en todo caso, la posibilidad de que la defensa la costee. 
Y, como hemos adelantado, si todas estas consideraciones son ciertas con carácter general para la prueba pericial, al referirlas específicamente a la prueba genética cobran más fuerza.

\subsection{Naturaleza Indiciaria}

Los análisis genéticos arrojan resultados que simplemente dan lugar al reconocimiento de un indicio y no una prueba directa sobre el delito, ni de la autoría o participación en él del acusado. Ello es de trascendental importancia teniendo en cuenta que la prueba indiciaria debe reunir unos requisitos para desvirtuar la presunción de inocencia.

Así, según reiterada jurisprudencia del Tribunal Constitucional y del Tribunal Supremo, "el derecho a la presunción de inocencia no se opone a que la convicción judicial en un proceso penal pueda formarse sobre la base de una prueba indiciaria, si bien esta actividad probatoria debe reunir una serie de exigencias para ser considerada como prueba de cargo suficiente para desvirtuar la presunción constitucional. Se coincide en resaltar como requisitos que debe satisfacer la prueba indiciaria los siguientes: que los indicios, que han de ser plurales y de naturaleza inequívocamente acusatoria, estén absolutamente acreditados, que de ellos fluya de manera natural, conforme a la lógica de las reglas de la experiencia humana, las consecuencias de la participación del recurrente en el hecho delictivo del que fue acusado y que el órgano judicial ha de explicitar el razonamiento en virtud del cual, partiendo de esos indicios probados, ha llegado a la convicción judicial de que el acusado realizó la conducta tipificada como delito" (STS de 28 de noviembre de 1997, RA 8561).

Los indicios, por tanto, deben ser plurales y deben, además, estar probados, debiendo el órgano judicial explicitar el razonamiento seguido para, partiendo de esos indicios probados, haber llegado a la conclusión de que el procesado realizó la conducta tipificada como delito (STC 94/1990, de 23 de mayo).

Así, la prueba genética dará lugar en el proceso penal, mediante las conclusiones presentadas por los peritos, a un indicio probatorio que el juzgador habrá de valorar, "razonando expresamente en la sentencia tanto los motivos que le llevan a considerar probado, en su caso, el indicio -esto es, la valoración del propio informe pericial- como el hecho que considera probado con base en tal indicio -, y, en este último caso, haciendo mención de las razones de su convicción y, así, su valoración en conjunción con otros indicios.

La importancia de la prueba genética también se relativiza por el hecho de que los indicios tendrán más o menos relevancia en función de otras circunstancias. Valga como ejemplo el que utiliza el Profesor FRAGOSO-ÁLVAREZ que se refiere al análisis de un pelo obtenido en el lugar en el que se cometió el asesinato. El resultado del 
reconocimiento pericial concluye con la coincidencia entre los marcadores genéticos del pelo y de la muestra del acusado. El hecho puede significar mucho o no significar nada según las circunstancias, y así según otra serie de indicios, que se presenten en el caso. Si el acusado no tiene motivo alguno que explique la aparición del cabello en el lugar de los hechos, la coincidencia producirá un indicio de gran valor. Por el contrario, si el acusado visita con asiduidad ese lugar, el indicio perderá toda su virtualidad probatoria. Mayor convicción cabrá adquirir de este indicio si, además, se produce el denominado "doble vínculo", a saber: junto al pelo obtenido del lugar del crimen se obtiene una mancha de sangre del pantalón que fue recuperado del domicilio del acusado, la cual, una vez analizada, da como resultado la coincidencia entre los marcadores genéticos de dicha mancha y la sangre de la víctima (LÓPEZ-FRAGOSO ÁLVAREZ, 1999, p. 212 y ss).

Del ejemplo expuesto se deduce claramente el valor indiciario del análisis genético, porque, en definitiva, la presencia del ADN de una persona en el lugar de los hechos no es concluyente. Simplemente demostrará su presencia y ello si no pensamos en que lo que se ha producido es una contaminación biológica anterior, posterior o previa, de manera que, en realidad, lo que puede haber sucedido es que esa persona ha estado con la persona asesinada antes de la comisión del crimen, o que se encontraba casualmente en el lugar de los hechos, o, bien, que posteriormente, antes del hallazgo del cadáver, pasó por allí3 ${ }^{37}$.

Su relatividad aumenta al considerar su naturaleza probabilística, de la que pasamos a ocuparnos a continuación y que supone, dicho en pocas palabras, que los resultados que arrojan estas pruebas deben medirse en términos de probabilidad respecto a la población de una región determinada.

Estas consideraciones no hacen sino matizar la importancia que la prueba genética debe tener en el proceso, un indicio que, en conjunción con otros, puede destruir la presunción de inocencia. En definitiva, lo que no puede aceptarse desde esta perspectiva es que si esto es así, la negativa a la práctica de estas diligencias sea considerada a su vez como un indicio, esto es, como si la prueba se hubiera practicado y, además, hubiera arrojado un resultado positivo, que, recordemos, se manifiesta en términos relativos o de probabilidad, no en términos absolutos.

${ }^{37}$ Por citar alguna posibilidad porque, como dice LORENTE ACOSTA/LORENTE ACOSTA (El ADN y la identificación..., op. cit., pág. 141), “...si en un caso determinado aparece una pequeña mancha de sangre (evidencia) en el pomo de una puerta, en un fragmento de baldosa o en un cenicero, en el momento de recogerla es inevitable que el investigador pueda arrastrar ADN de otras personas que, siendo ajenas al hecho criminal dejaron el mismo depositado al abrir la puerta, al pisar la baldosa o al manejar el cenicero. Este tipo de contaminación puede ser múltiple (en una baldosa que hay en el suelo pueden pasar muchas personas que arrastran en la suela de sus zapatos materiales biológicos de un origen muy variado, amén de que se pueden acumular pelos, restos de saliva, etc..., dificultan aún más la interpretación de los resultados)”. 


\subsection{Naturaleza Probabilística}

Analizaremos a continuación esta última cuestión, incidiendo en el papel que debe corresponder al juez, al abogado defensor y al Ministerio Fiscal, si bien, su naturaleza pericial, obliga a que sean los peritos actuantes ante los órganos jurisdiccionales a que actúen con el debido rigor y, en definitiva, explicando convenientemente en sede de práctica de la prueba, sus informes, con independencia de se hayan presentado previamente en la fase de instrucción.

En este sentido el Profesor CARRACEDO ÁLVAREZ afirma que "aunque coincidan los polimorfismos de ADN en la mancha y en el presunto culpable, el perito solo puede dar un valor probabilístico a esta coincidencia y nunca otorgarle la certeza absoluta, aunque, en muchos casos, la probabilidad de que esa mancha provenga del acusado sea científicamente elevada". Porque de lo que se trata es de que el perito le haga comprender al juez el significado de esos conceptos probabilísticos a fin de que el juez pueda evaluar la prueba científica de la forma más justa, incorporándola a otras pruebas de distinta naturaleza ${ }^{38}$.

En este proceso es esencial que el juez comprenda primero el concepto de probabilidad. Con independencia de la evolución que haya experimentado este concepto, la probabilidad podemos definirla, siguiendo nuevamente al Profesor CARRACEDO ÁLVAREZ, como "la medida de la verosimilitud que superpone un sistema de coordenadas numéricas a juicios comparativos del sentido común faltos, en parte, de estructuración. En definitiva, la incertidumbre se mide con un estándar que es la probabilidad".

Con esta definición no hacemos más que iniciarnos en el camino de la valoración de la prueba genética. El paso siguiente viene constituido por la exclusión en la interpretación de la prueba biológica de lo que este autor denomina "la falacia de la acusación y la falacia de la defensa".

Para comprender el significado de estos términos debemos considerar primero cómo deben interpretarse los resultados que arroja una prueba de ADN. Si el resultado es negativo, es decir, de no coincidencia de uno o más marcadores genéticos, el margen de error es despreciable, de manera que podemos decir que la mancha analizada no corresponde a esa persona, con un margen de error mínimo y que depende únicamente de la seguridad analítica del laboratorio. Ello quiere decir que, en esencia, la exclusión de una persona se consigue cuando en los indicios dubitados se encuentran fragmentos

38 CARRACEDO ÁLVAREZ, A., La valoración de la prueba en Criminalística, CGPJ, 1996, pág. 340. Concluye diciendo este autor que "la realidad es que todos los avances técnicos realizados con la introducción del polimorfismo del $A D N$ tendrán poco valor si no se acompañan con una presentación más correcta por el perito de los resultados de la prueba, y por un conocimiento suficientes por los jueces del significado de probabilidad y de cómo ésta se aplica para valorar este tipo de pericias". 
de ADN que no posee la persona acusada. Entonces, si se confirma la exclusión será total sin que sea necesario realizar cálculos estadísticos ${ }^{39}$.

El problema aparece cuando el resultado es positivo, o de coincidencia de uno o varios marcadores genéticos en la mancha analizada y en el material biológico obtenido del sujeto pasivo de la intervención corporal. En ese caso la pregunta que formula el juez es la siguiente, “¿cuál es la probabilidad de que esa mancha de sangre o ese pelo o ese esperma provengan de ese individuo?”. Es decir, entonces los resultados deben presentarse teniendo en cuenta los datos estadísticos poblacionales ${ }^{40}$.

La primera respuesta a esta pregunta puede parecer sorprendente porque aunque coincidan varios marcadores genéticos, afirma este experto en la materia, "siempre existirá una incertidumbre sobre si pertenece la mancha al individuo, que, repetimos, puede ser mínima, pero siempre es evaluable y no puede hablarse en ningún caso de incriminación o seguridad absoluta". Debe pues procederse a la valoración en términos de probabilidad de la coincidencia de grupos.

$\mathrm{Y}$ es entonces cuando se corre el peligro de presentar los resultados de manera equivocada o exagerada, cayendo en lo que hemos llamado "falacia de la acusación y de la defensa". Valga como ejemplo el siguiente, que relata el Prof. CARRACEDO en su trabajo: "Si se analiza un grupo de ADN y que la mancha y el acusado poseen el fenotipo 19-29, que lo posee una persona de cada cien... la prueba se puede presentar ante el juez, como ahora veremos, de forma muy diferente: El fiscal puede presentar el caso así: "El análisis del Laboratorio Forense tiene en este caso una enorme importancia. El grupo encontrado lo posee sólo el uno por cien de la población, de modo que sólo hay un uno por ciento de probabilidades de que la sangre provenga de otro que no sea el acusado. Es decir, solo hay el uno por ciento de probabilidades de que algún otro haya cometido el crimen, de modo que el acusado tiene un $99 \%$ de probabilidades de ser culpable". La defensa puede al contrario decir: "La prueba del laboratorio forense tiene una importancia muy escasa. Sólo el uno por ciento de la población posee ese grupo de ADN, pero en una ciudad como ésta... (supongamos que el crimen se cometió en Madrid) con unas 500.000 personas en edad de cometer el crimen, ese grupo será

${ }^{39}$ De ahí la importancia, que ya hemos recalcado en varias ocasiones, de que los laboratorios que realicen estos análisis sigan las recomendaciones de la ISFH (International Society for Forensic Haemogenetics), estando en tal sentido, debidamente acreditados.

En este sentido, LORENTE ACOSTA/LORENTE ACOSTA (El ADN y la identificación..., op. cit., págs. 183 y ss) advierten de que ese criterio es esencial para dotar de validez a los informes presentados, pero, además, los informes deberán incluir los tipos de técnicas empleadas y el fenotipo de los marcadores analizados, la probabilidad de coincidencia y discriminación y, en su caso, la tasa de error a priori.

${ }^{40}$ Debemos excluir los supuestos en que, como consecuencia de una contaminación genética, aparecen en el resultado analítico una serie de alelos que corresponden a más de un individuo y entre los que se encuentra el genotipo del sospechoso. En estos casos, la conclusión analítica debe ser que "el individuo no puede ser excluido", lo que no debe ser interpretado ni como una exclusión, ni como una inclusión con una probabilidad determinada. (V. LORENTE ACOSTA/LORENTE ACOSTA, El ADN y la identificación..., op. cit, pág.185). 
encontrado en 5.000. El ADN muestra pues que el acusado es una de las 5000 personas de la ciudad que pudo haber cometido el crimen. Una posibilidad en 5.000 tiene una importancia escasísima para que se considere a esa persona culpable".

Pero es que ninguno de estos dos argumentos es correcto y se han denominado la falacia del fiscal y de la defensa.

Para hacer una correcta valoración de los resultados obtenidos tras el análisis genético debemos acudir al análisis Bayesiano. El teorema de Bayes "es una consecuencia inmediata de la ley de la multiplicación que sirve para conocer las probabilidades finales de un suceso a partir de las probabilidades inciales, dada cierta información o informaciones adicionales obtenidas".

Este es el teorema que debe aplicar el juez para valorar objetivamente la prueba científica. Así, el juez no tendrá más que multiplicar su grado de creencia previo sobre la culpabilidad del acusado, expresado en forma de apuesta, por un factor que el perito debería proporcionar siempre al juez y que se denomina "likelihood ratio" o razón de verosimilitud y que es el resultado de contemplar la probabilidad de encontrar el hallazgo científico dada la culpabilidad, y la probabilidad de encontrar el hallazgo científico dada la inocencia. De esta manera el perito evita caer en la falacia de la defensa o de la acusación y contempla ambas posibilidades.

En un ejemplo el perito debería razonar de la siguiente manera: la probabilidad de que una mancha de sangre provenga de ese individuo si es culpable es 1 (100\%). Pero, bajo la hipótesis de la no culpabilidad o inocencia, la probabilidad del hallazgo es la misma que la de que un hombre al azar de la población posea el mismo fenotipo 19-29. Es decir, 0.01 (1\%). Si aplicamos la fórmula de la razón de la verosimilitud (LR), resulta que ésta es 100 (1/0.01). Esto significa que la probabilidad de la culpabilidad de ese individuo en forma de apuesta se habrá multiplicado por 100.

Es entonces cuando debe tenerse en cuenta el criterio que tenía el juez a favor o en contra de la culpabilidad antes de conocer el resultado de la prueba científica. En un ejemplo, si el juez con las otras pruebas considera que es inocente con muchas posibilidades (1000 a 1 a favor de la inocencia) después de la prueba de ADN, con una razón de verosimilitud igual a 100, sigue teniendo muchas posibilidades de ser inocente (10 a 1 a favor de su inocencia, ya que este es el resultado de 0.001 x $100=0.1$ ). Si por el contrario el juez estima que tiene tantas posibilidades de ser inocente como de ser culpable, podrá apostar de forma objetiva 100 contra 1 a favor de su culpabilidad.

El ejemplo expuesto es bastante significativo y refleja la complejidad de la valoración de la prueba científica. El análisis bayesiano no resulta fácil de comprender para los hombres de leyes, pero es el único sistema justo para valorar la prueba científica.

Profundizando un poco más sobre la cuestión, para determinar la probabilidad de culpabilidad dada la prueba científica, debemos considerar la probabilidad a priori, y esto es competencia exclusiva del juez y no del perito. Ello ha llevado a cometer importantes errores ya que, a veces, el perito ocupa el lugar del juez y asigna 
automáticamente un valor de 0.5 a la probabilidad a priori, es decir, tantas probabilidades de ser culpable como inocente. Si expresamos la probabilidad de que el individuo sea culpable (P (C)) como el resultado de aplicar la siguiente fórmula, resulta evidente que se van a falsear los resultados.

En un ejemplo se ve claro. En el caso Collins de 1968, una mujer mayor fue arrojada al suelo y robada en Los Ángeles, y un testigo vio corriendo a una mujer blanca con pelo rubio y cola de caballo que entró en un coche amarillo, conducido por un hombre negro con barba y bigote. La policía arrestó a una pareja que presentaba características similares, pero no había más pruebas que los acusaran. El perito aplicó la regla de la independencia y consideró que:

Características:

Automóvil amarillo

Hombre con bigote

Mujer con cola de caballo

Mujer con pelo rubio

Hombre negro con barba

Pareja interracial en coche

$1 / 1000$

De estos datos el Ministerio Fiscal concluyó que había una posibilidad en doce millones de que una pareja seleccionada al azar encajase en estas características. El jurado los condenó. Posteriormente, el Tribunal Supremo de California revocó la sentencia, al considerar que el testimonio del perito era erróneo ya que no se ajustaba a la teoría de las probabilidades. En definitiva, si la probabilidad a priori era muy baja (no había más pruebas que el testimonio de una mujer), la probabilidad a posteriori también lo sería. Porque lo cierto es que si se busca una pareja con estas características, probablemente se encuentre, y ello no quiere decir que sea culpable.

De lo dicho se desprende, de un lado la importancia de que el dato de la probabilidad a priori de la culpabilidad la proporcione el juez, sino se falsearán los resultados y, de otro, el hecho de que el resultado que se obtiene incluso en los supuestos en que la pericia de ADN da como resultado la inclusión, puede ser relativo. Para evaluarlo hay que acudir a las probabilidades, contempladas desde dos perspectivas o hipótesis alternativas, y expresada como una proporción entre ambas. Si no se caería en la falacia de la acusación o de la defensa (CARRACEDO ÁlVAREZ, 1999, p. 301-308; 1996, p. 339-358).

Lo dicho corrobora aún más el valor indiciario de la prueba genética, que debe ser tenida en consideración conjuntamente con otros medios de prueba incriminatorios para el acusado. En este proceso resulta particularmente interesante el modo en que se presenten los resultados porque, KOEHLER demostró en un amplio estudio que, si se presentan en términos matemáticos $(0.1,0.01,0.001 .$.$) , los jurados tienden a considerar culpable a un$ acusado con mayor facilidad que si se presentan en términos de frecuencia ( 1 entre 1000, 
1 entre 10.000, 1 entre 100.000) porque, significando exactamente lo mismo, se ha dado entrada a la posibilidad de que otras personas distintas posean los mismos marcadores genéticos. Si se presentan en ambos modos, entonces no se aprecian diferencias, los jurados tienden a considerar culpable o inocente a un acusado sin que influya el modo de informar de los peritos.

Ello demuestra la necesidad de que los órganos jurisdiccionales conozcan mínimamente la técnica pericial de $\mathrm{ADN}$ y de los problemas que puede ocasionar su uso inadecuado o incorrecto. Resulta, por ejemplo, conveniente que los peritos informen en términos de probabilidad y de frecuencia, por ejemplo, como hace el Tribunal Supremo en la STS de 13 de mayo de 1998 (RA 8278, 1998), en la que se dice expresamente que "el Instituto Nacional de Toxicología certifica que mediante técnica de identificación de ADN se ha comprobado que las características de las células epiteliales recuperadas en el dispositivo intrarectal...coinciden con las correspondientes a M.A. B..Y., y que la frecuencia de estas características genéticas en la población es de 0.29 por cien, es decir, de veintinueve de cada diez mil individuos..." ${ }^{41}$.

Todo ello nos lleva de nuevo a reclamar la presencia de los peritos en la fase de juicio oral, dando oportunas explicaciones sobre el modo en que se han obtenido los resultados derivados de la prueba genética y, también, informando convenientemente en relación a los resultados obtenidos en relación al caso concreto y a la determinada población o subpoblación a que pertenezca el acusado o las muestras biológicas analizadas ${ }^{42}$.

Su presencia es necesaria sobre todo desde el prisma de reclamar una adecuada interpretación y valoración de las pruebas, para, en definitiva, trasladar su razonamiento o informe a la motivación de la decisión judicial.

\section{A MODO DE CONCLUSIÓN}

La conclusión obtenida confirma la posición inicial según la cual la imposición coactiva, en las condiciones y con los presupuestos vistos, de una leve y mínima intervención corporal (extracción sanguínea, corte de cabellos...), siempre que el sujeto pasivo de la misma fuese el imputado, acusado o procesado, supone desde el punto de vista del derecho de defensa de la parte mayores garantías que el considerar la negativa al sometimiento como un indicio de la comisión de los hechos, con la previa salvaguarda

\footnotetext{
${ }^{41}$ Cosa distinta es que para la obtención de este resultado se haya seguido correctamente en análisis bayesiano, circunstancia que desconocemos.

${ }^{42}$ Este dato es esencial, así, como ponen de relieve LORENTE ACOSTA/LORENTE ACOSTA (El ADN y la identificación..., op. cit., págs. 193-194), "si unos genotipos son frecuentes en una población, podríamos obtener que dicho perfil genético se da en uno de cada diez mil individuos de la población, mientras que si en la subpoblación existente dentro del grupo poblacional anterior son poco frecuentes, se daría en un individuo de cada cien mil. Lógicamente, no es igual un caso que otro".
} 
de sus derechos fundamentales conforme a la previa autorización legal de la intervención corporal, adecuada a las exigencias de la proporcionalidad y razonabilidad de la medida (art. 363.2 LECrim.).

La impunidad que se procura el agresor de la víctima de violencia sexual, con las dificultades que nos encontramos en sede probatoria al no existir prácticamente otro medio de prueba, determinan la viabilidad de las mismas, según el juicio de proporcionalidad que debe plasmar el juez en la autorización de la medida, al resultar tal intervención corporal no sólo necesaria e idónea, sino también proporcional en sentido estricto, al suponer una restricción a los derechos del imputado plenamente justificada al no poder adoptarse otra medida menos lesiva para el imputado que resulte eficaz para la realización de los fines del proceso penal ${ }^{43}$.

No obstante, por el contrario, la práctica de estas diligencias de intervención corporal en relación a la víctima de delitos violentos, particularmente en el ámbito de los delitos contra la libertad sexual, donde su reconocimiento por parte del personal médico resulta fundamental para la búsqueda y recogida de vestigios biológicos provenientes del autor de los hechos (semen, saliva, pelos...) y resultan esenciales para la identificación del delincuente, debe respetar en todo caso la intimidad de la víctima, sin que sea sometida a trato inhumano o degradante alguno, con la previa prestación de su consentimiento informado. Si la víctima no autorizase la intervención corporal, únicamente, siguiendo el modelo del Derecho Alemán, debiera permitirse la práctica de aquellas diligencias que consistan en la búsqueda de las huellas del delito "sobre el cuerpo" o "entre las ropas", no "en el cuerpo" de la víctima, por mucho que en el Derecho Alemán el recurso a la coerción física se admita sin reservas para la práctica de diligencias de intervención corporal sobre el imputado ${ }^{44}$.

La valoración indiciaria y probabilística de los informes genéticos confirman esta tesis inicial, debiendo, no obstante, rodear a la práctica de la prueba pericial, particularmente de la prueba de ADN, de todos los requisitos examinados y que deben observarse para lograr su eficacia y adecuada valoración e interpretación por el juez al dictar sentencia ${ }^{45}$.

${ }^{43}$ Sobre el principio de proporcionalidad v. GONZÁLEZ-CUÉLLAR SERRANO. N., Proporcionalidad..., op. cit., Madrid, 1990.

${ }^{44}$ En relación a quienes pueden ser sujeto pasivo de las intervenciones corporales y en qué condiciones y presupuestos y con qué límites v. mi trabajo sobre Investigación penal..., op. cit., págs. 81 y ss.

${ }^{45}$ Debe recordarse que, residualmente, sobre todo en relación con los registros e inspecciones corporales, incluso sobre el imputado, no debe considerarse la posibilidad de su imposición coactiva porque ello sería desproporcionado y lesivo para el derecho de defensa de la parte, de modo que, en tales situaciones resulta preferible optar por la consideración de la negativa como un indicio en su contra. 


\section{REFERÊNCIAS}

ALAÑÓN OLMEDO F. (Algunos apuntes sobre el contenido del artículo 416 de la Ley de Enjuiciamiento Criminal), "Violencia de género: perspectiva jurídica y psicosocial", Tirant lo Blanch, Valencia, 2009, págs. 63 y ss.).

ARRACEDO ÁLVAREZ, A., Valoración de la prueba del ADN, "La prueba de ADN", Medicina Forense, 1999, Barcelona, págs. 301-308; Idem, La valoración de la prueba de ADN .., op. cit., págs. 339-358.

CARRACEDO ÁlVAREZ, A., La valoración de la prueba en Criminalística, CGPJ, 1996, pág. 340.

DÍAZ CABIALE J. A., MARTÍN MORALES, R., La garantía constitucional..., op. cit., págs. 88 y ss. y 110 .

DÍAZ CABIALE, J. A., MARTÍN MORALES, R., La garantía constitucional de la inadmisión de la prueba ilícitamente obtenida, Madrid, 2001, págs. 22-33.

En este sentido, LORENTE ACOSTA/LORENTE ACOSTA (El ADN y la identificación..., op. cit., págs. 183 y ss)

FABREGA RUIZ, C. F., Aspectos jurídicos de las nuevas técnicas de investigación criminal, con especial referencia a la "huella genética" y su valoración judicial, "La Ley", núm. 4721, págs. 3-4.

GONZÁLEZ-CUÉLLAR SERRANO (Proporcionalidad y derechos fundamentales en el proceso penal, Madrid, 199.

IGLESIAS CANLE, I. C, C. “Investigación penal sobre el cuerpo humano y prueba científica”, Madrid, 2004 , págs. 14 y ss.

IGLESIAS CANLE, I. C, La nueva regulación de las medidas de intervención corporal en el art. 363.2 LECrim.: la quiebra del principio de legalidad, págs. 175 y ss.

JUANES PECES, A., La prueba prohibida. Análisis de la sentencia 81/1998 del Tribunal Constitucional. Un nuevo enfoque de la presunción de inocencia, AJA, 30 de julio de 1998, núm. 353, págs. 1-5; LÓPEZ ORTEGA, J. J., Prueba y proceso penal. El alcance derivado de la prueba ilícita en la jurisprudencia constitucional (A propósito de la STC 81/1998), "Derecho y Proceso penal”, 1999, núm. 1, págs. 123 y ss.; MARTÍ SÁNCHEZ, N., La llamada "prueba ilícita” y sus consecuencias procesales, AP, 19998, t. I., núm. 7, págs. 141-162.

LÓPEZ ORTEGA, J. J., Prueba y proceso penal.., op. cit., págs. 123 y ss.

LÓPEZ-FRAGOSO ÁLVAREZ, T., El análisis de ADN en el proceso penal, La Laguna, 1999, pág. 212 y ss.

LORENTE ACOSTA/LORENTE ACOSTA ( $E l$ ADN y la identificación en la investigación criminal y en la paternidad biológica, Granada, 1995, págs. 195 y ss.)

LORENTE ACOSTA/LORENTE ACOSTA, El ADN y la identificación..., op. cit, pág.185).

MIRANDA ESTRAMPES (El concepto de prueba ilícita y su tratamiento en el proceso penal, Barcelona, 1999, págs. 15 y ss.) 
MIRANDA ESTRAMPES (El concepto de prueba ilícita y su tratamiento en el proceso penal, Barcelona, 1999, págs. 995 y ss.)

PÉREZ MARÍN, M. A., Inspecciones, registros e intervenciones corporales. Las pruebas de ADN y otros métodos de investigación en el proceso penal, Valencia, 2.008.

SANZ HERMIDA, A., Notas de Derecho Procesal Angloamericano, Revista General del Derecho, 18, 2009. 